\title{
Seasonal and interannual variability in population dynamics of planktic foraminifers off Puerto Rico (Caribbean Sea)
}

\author{
Anna Jentzen $^{1, \mathrm{a}}$, Joachim Schönfeld ${ }^{1}$, Agnes K. M. Weiner ${ }^{2, \mathrm{~b}}$, Manuel F. G. Weinkauf ${ }^{2,3}$, \\ Dirk Nürnberg ${ }^{1}$, and Michal Kučera ${ }^{2}$ \\ ${ }^{1}$ GEOMAR Helmholtz Centre for Ocean Research Kiel, 24148 Kiel, Germany \\ ${ }^{2}$ MARUM Center for Marine Environmental Sciences, University of Bremen, 28359 Bremen, Germany \\ ${ }^{3}$ Department of Earth Sciences, University of Geneva, 1205 Geneva, Switzerland \\ ${ }^{\mathrm{a}}$ current address: Department of Climate Geochemistry, \\ Max Planck Institute for Chemistry, 55128 Mainz, Germany \\ ${ }^{b}$ current address: Department of Biological Sciences, Smith College, Northampton, MA 01063, USA
}

Correspondence: Anna Jentzen (anna.jentzen@mpic.de)

Received: 19 June 2019 - Revised: 18 November 2019 - Accepted: 19 November 2019 - Published: 20 December 2019

\begin{abstract}
The state of a population of planktic foraminifers at a certain time reflects multiple processes in the upper ocean, including environmental conditions to which the population was exposed during its growth, the age of the cohorts, and spatiotemporal patchiness. We carried out depth-stratified $(0-60,60-100 \mathrm{~m})$ replicated sampling off Puerto Rico in autumn 2012, revisiting three stations previously sampled in autumn 1994 and spring 1995, in order to analyze seasonal and interannual variability of planktic foraminifers and the stable isotopic composition of their tests. The merged dataset from all three sampling campaigns allows us to assess short- and long-term changes in foraminiferal population dynamics and the spatial assemblage coherency along the shelf edge. All three sample series cover more than 2 weeks during either spring (1995) or autumn (1994, 2012) and include the time of the full moon when reproduction of some surface-dwelling planktic foraminifers has been postulated to take place. Our analyses indicate that interannual variability affected the faunal composition, and both autumn assemblages were characterized by oligotrophic tropical species, dominated by Trilobatus sacculifer and Globigerinoides ruber (white and pink variety). However, G. ruber (white) had a higher abundance in 1994 (37\%) than in 2012 (3.5\%), which may be partially due to increasing sea surface temperatures since the 1990s. Between 60 and $100 \mathrm{~m}$ water depth, a different faunal composition with a specific stable oxygen isotope signature provides evidence for the presence of the Subtropical Underwater at the sampling site. Measurements on T. sacculifer sampled in autumn 2012 revealed that test size, calcification and incidence of sac-like chambers continued to increase after full moon, and thus no relation to the synodic lunar reproduction cycle was recognized. During autumn 2012, outer bands of hurricane Sandy passed the Greater Antilles and likely affected the foraminifers. Lower standing stocks of living planktic foraminifers and lower stable carbon isotope values from individuals collected in the mixed layer likely indicate the response to increased rainfall and turbidity in the wake of the hurricane.
\end{abstract}




\section{Introduction}

Planktic foraminifers are unicellular marine eukaryotes that live in the open ocean and build calcareous shells (called tests) around their cell. Their assemblage composition in different water masses and the stable isotope composition of their tests are widely used as proxies to reconstruct past ocean conditions (e.g., Fischer and Wefer, 1999; Kučera, 2007; Schiebel et al., 2018). Prevailing water mass conditions can influence the distribution of planktic foraminifers in various ways. Studies on plankton tows have shown that, for example, seasonal changes in temperature, food availability (chlorophyll concentration), and upwelling conditions influence the assemblage composition and standing stocks (e.g., Bé, 1977; Schiebel et al., 2001; Retailleau et al., 2011; Jentzen et al., 2018b). Additionally, foraminiferal assemblages in the water column are marked by small-scale spatial variability (patchiness; Siccha et al., 2012; Meilland et al., 2019) and also variability in the proportion between different ontogenetic stages (juvenile and adult individuals). It has been suggested that the reproduction of various species follows a lunar or semilunar periodicity (Spindler et al., 1979; Almogi-Labin, 1984; Bijma et al., 1990). The evidence is based on a laboratory culturing experiment, in which the majority of individuals of a certain morphospecies reproduced around the same day (Spindler et al., 1979) and is supported by field observations on changes in abundance and size of individuals in the water column (e.g., Bijma et al., 1990; Schiebel et al., 1997; Jentzen et al., 2018b), as well as by sediment trap series that reflect a periodic flux of tests (Lončarić et al., 2005; Jonkers et al., 2015). Stable isotopes in foraminiferal tests allow us to assess the physical properties of the ambient water column when the foraminifer calcified (e.g., Steph et al., 2009); however, studies from living planktic foraminifers reveal species-specific offsets to the seawater isotopic composition (Spero and Lea, 1993; Jentzen et al., 2018a).

To add to our understanding of regional assemblage structure changes over different timescales, we collected living specimens off the southern coast of Puerto Rico and revisited the sampling sites of Schmuker (2000a, b) from September to October 1994 and March 1995. The previous studies assessed the influence of neritic environmental conditions and their seasonal changes on living planktic foraminiferal assemblages. In particular, they revealed a seasonal influence of the Orinoco River outflow plume on the southern coast of Puerto Rico, which leads to eutrophic conditions in autumn. A higher abundance of planktic foraminifers was consequently observed in autumn, with Globigerinoides ruber (pink and white) as dominant species, while Globigerinella calida was the most abundant species during oligotrophic conditions in spring. The studies additionally revealed a faunal gradient from neritic environments near the coast to offshore conditions, with lower standing stocks close to the shelf break. Shallow-water benthic foraminifers were found in plankton tows as well. Some of those benthic species, for instance Tretomphalus bulloides, have a planktic stage during their life cycle (meroplanktic life cycle; Rückert-Hilbig, 1983). Others were probably brought in suspension on the shelf and transported further offshore (Schmuker, 2000b; Fornshell, 2005). Stable isotope measurements of the planktic foraminifer G. ruber (white), conducted by Schmuker (2000b), showed lower values of $\delta^{13} \mathrm{C}_{\mathrm{CALCITE}}$ during autumn compared to spring, which might indicate reduced photosynthesis of the symbionts of the foraminifers due to higher turbidity of the upper water column or reduced light attenuation during the rainy season. This assumption refers to the hypothesis of Spero and Lea (1993) that decreasing light levels lower metabolic activity of the symbionts and thereby reduce photosynthetic fixation of ${ }^{12} \mathrm{C}$ in the calcifying foraminiferal microenvironment.

The results of Schmuker (2000a, b) from 1994 and 1995 are used as baseline data to assess long-term changes in the foraminiferal assemblage that happened during the past 17 years. In our study, we repeatedly collected living planktic foraminifers over 2 weeks in 2012 at three stations and two depth intervals off the southern coast of Puerto Rico. The sampling sites of 2012 were close to those chosen by Schmuker in 1994 and 1995 (Schmuker, 2000b; Fig. 1). We intended to determine the dynamics and spatial distribution of the foraminiferal assemblage on a weekly and decadal perspective. Stable isotopes $\left(\delta^{18} \mathrm{O}\right.$ and $\left.\delta^{13} \mathrm{C}\right)$ were measured in tests of $G$. ruber (pink) and related to in situ temperature and $\delta^{18} \mathrm{O}_{\text {SEAWATER }}$. Since the time span of our sampling campaign extended over the full moon, we measured size and weight changes in the tests of Trilobatus sacculifer, which may be related to synchronized reproduction, and monitored their approximate living depth to detect ontogenetic migration. During the sampling campaign in 2012, hurricane Sandy passed the Greater Antilles. We used this unforeseen opportunity to examine the impact of such a storm on the foraminiferal assemblage.

Our goal within this study is to assess the population dynamics of living planktic foraminifers on a weekly, seasonal, and interannual timescale, and to evaluate the spatial assemblage coherency along the shelf edge to improve our understanding of short- and long-term variations. The results will ultimately help to improve the applicability of foraminiferal paleoproxies.

\section{Regional settings}

The southwestern margin of Puerto Rico is characterized by a very steep slope, which commences at $20 \mathrm{~m}$ water depth on the shelf and extends to $1000 \mathrm{~m}$ water depth. This slope was probably created by the counterclockwise rotation of the Puerto Rico block and associated strike-slip movements along the branches of the Great Southern fault zone (Glover, 1971; Byrne et al., 1985; Masson and Scanlon, 1991). Dif- 


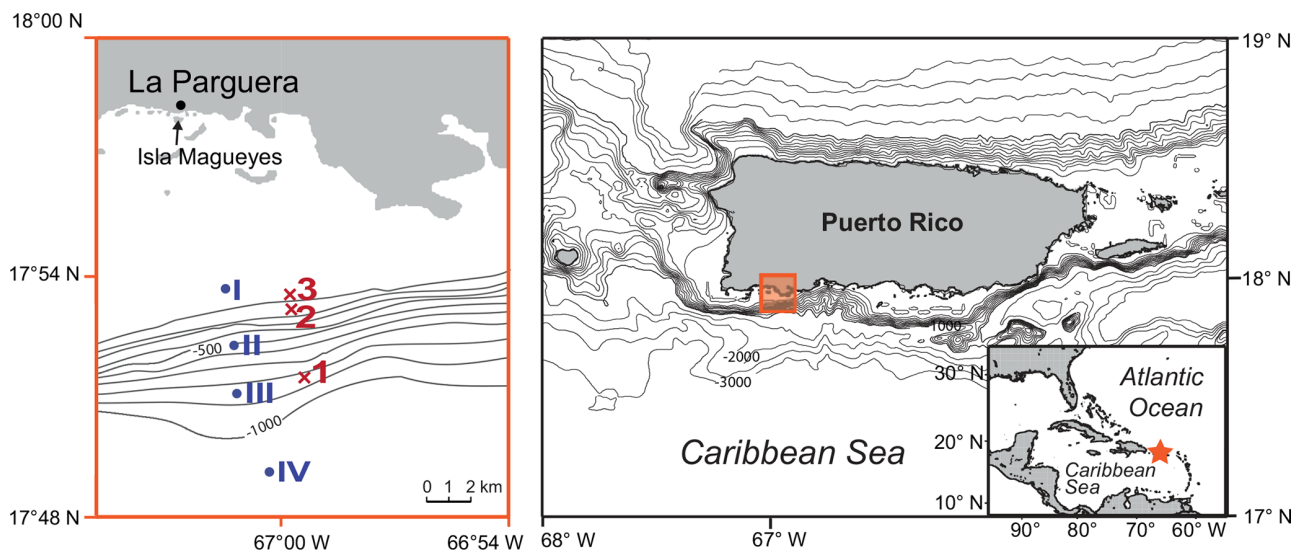

Figure 1. Location of the study area in southwestern Puerto Rico (Caribbean Sea). The red crosses mark the plankton net stations of this study $(1-3 ; 2012)$ and the blue dots mark the plankton net stations of Schmuker (2000b; I-IV; 1994/1995; see Table 1). The maps were generated at https://sfb574.geomar.de/gmt-maps.html (last access: 28 November 2012).

ferent water masses impinge the slope in our study area. The uppermost water mass is the Caribbean Water (CW, between 0 and 50-80 m depth), which is a mixture of the Amazon and Orinoco River outflow and North Atlantic surface water, with low salinity of $<35.5$ (Gordon, 1967; Schmuker, 2000b). The highly saline Subtropical Underwater (SUW, > 37 salinity) prevails between 50 and $250 \mathrm{~m}$. The $18^{\circ} \mathrm{C}$ Sargasso Sea Water and the Tropical Atlantic Central Water belong to the water mass at depths below $250 \mathrm{~m}$ (Gordon, 1967; Morrison and Nowlin, 1982; Gallegos, 1996). From August to November, surface waters in the southeastern Caribbean Sea are influenced by plumes of the Amazon and Orinoco rivers (Chérubin and Richardson, 2007), which result in silicaterich and low-salinity surface waters (Froelich et al., 1978; Corredor and Morell, 2001). From June to November, the Atlantic hurricane season affects the Caribbean Sea, inducing a thorough mixing of the upper water column (Jacob et al., 2000; Blake et al., 2013; NHC, 2014).

\section{Materials and methods}

\subsection{Sample collection in 2012}

The sampling campaign in 2012 took place at three different stations off southern Puerto Rico and on $4 \mathrm{~d}$ within 2 weeks from October to November (Fig. 1, Table 1). The stations were located on the upper slope (station 1: $850 \mathrm{~m}$ water depth), shelf edge (station 2: $150 \mathrm{~m}$ ), and on the shelf (station 3: $20 \mathrm{~m}$ ). An Apstein net (Hydro-Bios) and an open plankton net were used to collect living planktic foraminifers. At station 1 and station 2, the Apstein net with a mesh size of $100 \mu \mathrm{m}$ and an aperture of $17 \mathrm{~cm}$ in diameter was used to sample the $0-60$ and $60-100 \mathrm{~m}$ depth intervals. The net was hauled twice to double the volume of the filtered water during each haul. A trigger weight was attached to the rope, which released the shutter and closed the aperture of the net afterwards. The open plankton net, which was used at station 3, also had a mesh size of $100 \mu \mathrm{m}$ but an aperture of $40 \mathrm{~cm}$ in diameter. Because of the shallow depth of about $20 \mathrm{~m}$, vertical sampling was not possible. Instead, the open net was pulled with the boat for 5 min horizontally in the upper $5 \mathrm{~m}$ of the water column. The collected plankton samples were transferred to PVC vials, diluted with filtered ambient seawater, and brought to the laboratory within $2 \mathrm{~h}$ after sampling for further processing. In addition to the plankton net hauls, salinity and temperature were measured in situ using a hand-held conductivity meter (WTW LF 320 with a TetraCon 325 conductivity cell) in the upper $25 \mathrm{~m}$ of the water column at stations 1 and 2 and down to $10 \mathrm{~m}$ water depth at station 3 . The precision of the conductivity meter is 0.1 units, the accuracy is 0.116 units $(1 \sigma)$. Seawater samples of the surface waters for stable oxygen isotopes were taken with a bucket and stored in $100 \mathrm{~mL}$ glass bottles.

\subsection{Sample preparation}

In the laboratory of the marine station of the University of Puerto Rico at Isla Magueyes, foraminifers were immediately wet-picked from the plankton net samples and collected in Plummer cell slides. Samples that could not be picked on the same day of sampling were preserved in a $50 \%$ ethanolseawater solution and stored at $4{ }^{\circ} \mathrm{C}$.

All tests of planktic foraminifers were filled with cytoplasm (i.e., yellowish, greenish-grey, or green cytoplasm) indicating that they were alive at the time of collection. The specimens were identified on a morphospecies level following the taxonomy of Bé (1967) and Schiebel and Hemleben (2017). For Trilobatus sacculifer we differentiated the individuals with a sac-like final chamber (T. sacculifer with sac) from the trilobus-morphotype with a regular, spherical terminal chamber ( $T$. sacculifer without sac). We dis- 
Table 1. Station list with latitude, longitude, water depth (m), sampling date, and sampling depth (m) from this study and Schmuker (2000b).

\begin{tabular}{|c|c|c|c|c|c|}
\hline Station & Latitude & Longitude & $\begin{array}{r}\text { Water depth } \\
(\mathrm{m})\end{array}$ & $\begin{array}{l}\text { Sampling date } \\
\text { (day/month/year) }\end{array}$ & $\begin{array}{l}\text { Sampling depth } \\
\text { (m) }\end{array}$ \\
\hline $1^{\mathrm{a}}$ & $17^{\circ} 51.5^{\prime} \mathrm{N}$ & $66^{\circ} 59.13^{\prime} \mathrm{W}$ & 850 & $\begin{array}{l}22 \text { Oct } 2012 \\
29 \text { Oct } 2012 \\
2 \text { Nov } 2012 \\
5 \text { Nov } 2012\end{array}$ & $0-60,60-100$ \\
\hline $2^{\mathrm{a}}$ & $17^{\circ} 53.13^{\prime} \mathrm{N}$ & $66^{\circ} 59.49^{\prime} \mathrm{W}$ & 150 & $\begin{array}{l}22 \text { Oct } 2012 \\
29 \text { Oct } 2012 \\
2 \text { Nov } 2012 \\
5 \text { Nov } 2012\end{array}$ & $0-60,60-100$ \\
\hline $3^{\mathrm{a}}$ & $17^{\circ} 53.25^{\prime} \mathrm{N}$ & $66^{\circ} 59.51^{\prime} \mathrm{W}$ & 20 & $\begin{array}{l}29 \text { Oct } 2012 \\
2 \text { Nov } 2012\end{array}$ & 5 \\
\hline $\mathrm{I}^{\mathrm{b}}$ & $17^{\circ} 53.6^{\prime} \mathrm{N}$ & $67^{\circ} 1.48^{\prime} \mathrm{W}$ & 20 & $\begin{array}{l}\text { Oct } 1994 \\
\text { Mar } 1995\end{array}$ & $0-10$ \\
\hline $\mathrm{II}^{\mathrm{b}}$ & $17^{\circ} 52.3^{\prime} \mathrm{N}$ & $67^{\circ} 1.3^{\prime} \mathrm{W}$ & 500 & $\begin{array}{l}\text { Sep-Oct } 1994 \\
\text { Mar } 1995\end{array}$ & $0-120$ \\
\hline $\mathrm{III}^{\mathrm{b}}$ & $17^{\circ} 51.18^{\prime} \mathrm{N}$ & $67^{\circ} 1.3^{\prime} \mathrm{W}$ & 900 & $\begin{array}{l}\text { Sep-Oct } 1994 \\
\text { Mar } 1995\end{array}$ & $0-120$ \\
\hline $\mathrm{IV}^{\mathrm{b}}$ & $17^{\circ} 49.12^{\prime} \mathrm{N}$ & $67^{\circ} 0.36^{\prime} \mathrm{W}$ & 1300 & $\begin{array}{l}\text { Sep-Oct } 1994 \\
\text { Mar } 1995\end{array}$ & $0-120$ \\
\hline
\end{tabular}

${ }^{\mathrm{a}}$ This study. ${ }^{\mathrm{b}}$ Schmuker (2000b).

tinguished between Globigerinoides ruber (white), G. ruber (pink), and G. elongatus following Aurahs et al. (2011).

Benthic foraminifers in the plankton net haul samples were sorted into separate Plummer cell slides by species, fixed with glue, and counted. Specimens of Bolivina variabilis were filled with orange-red cytoplasm indicating that they were alive at the time of sampling (Kučera et al., 2017). Tretomphalus bulloides contained yellowish-brown cytoplasm as described by Cushman (1922) from living individuals. Three Cibicidoides pachyderma specimens contained a greenish-brown granular infill, which was interpreted as cytoplasm. Other individuals and species were empty and the tests were dull, indicating that they were probably not alive at the time of collection.

\subsection{Foraminiferal assemblage analyses}

To determine the relationship between species abundance, faunal composition, environmental factors, and time, different statistical methods were used in this study. Paired sample $t$ tests (abundance of paired species within two samples) and hierarchical cluster analyses with the Bray-Curtis similarity were performed using the software PAST v.3.14 (Hammer et al., 2001). These analyses test and visualize the similarity within and between each of the different assemblages from sample stations (1-3) in 2012. Nonmetric multidimensional scaling (NMDS; Kruskal, 1964) was used to compare the
2012 assemblage with assemblages from the same locations sampled in 1994 and 1995 by Schmuker (2000b). NMDS is a form of ordination that allows one to project the multidimensional assemblage data into a 2-D space for better visualization of the similarities and differences of assemblages observed across the decades. For this, we used the R package "vegan" v. 2.0-10 in R v. 3.1.0 framework (R Core Team, 2014). For the NMDS, the dataset by Schmuker (2000b) was reduced to the same species that we found in 2012 (Table 2), in order to eliminate an overly strong influence of rare species. Additionally, we limited the comparison to our stations 1 and 2, which correspond to stations III and II in Schmuker (2000b), respectively (see Fig. 1), because station 3 used a different sampling scheme making it incomparable. Schmuker (2000b) sampled the complete 0$120 \mathrm{~m}$ interval at once; therefore, we combined our stratified data to represent the complete $0-100 \mathrm{~m}$ depth interval for this step. Only the fraction $>150 \mu \mathrm{m}$ was analyzed in Schmuker (2000b); therefore, Turborotalita quinqueloba and Globoturborotalita rubescens are excluded from the analyses, because they are commonly smaller in diameter than $150 \mu \mathrm{m}$ and would thus be overrepresented in our samples $>100 \mu \mathrm{m}$. The rare species Pulleniatina obliquiloculata and Candeina nitida were excluded for the NMDS analyses as well in order to emphasize the assemblage changes with a focus on abundant taxa. The standing stock of the foraminiferal assemblage is given as individuals per cubic 
meter (ind. $\mathrm{m}^{-3}$ ). The filtered seawater volume was estimated by multiplying the lengths of the net hauls with the opening net aperture area.

\subsection{Test size and weight analyses of Trilobatus sacculifer}

Since the time span of our sampling campaign in 2012 extended over the full moon, we analyzed size and weight changes of Trilobatus sacculifer to test for lunarsynchronized reproduction (Erez et al., 1991). Therefore, all 655 intact and cytoplasm-bearing individuals of $T$. sacculifer (622 specimens without sac, 33 specimens with sac) from stations 1 and 2 were picked from the dried plankton samples. We chose to use T. sacculifer for two reasons: (1) it had a sufficiently large population size so that resulting morphometric analyses would be robust, and (2) it consists of only one genotype (André et al., 2013), so any observed changes could not be the result of changes in the inventory of cryptic species.

Individual foraminifers were photographed using a binocular stereomicroscope with a Canon EOS 600D camera. The length of each individual was manually measured as a straight line along the longest visible axis of the shell, i.e., maximum test diameter on the basis of these photographs using the program FIJI v. 1.47q (Schindelin et al., 2012). All subsequent statistical analyses were performed in SPSS v. 20 (IBM Corporation, 1989-2011). Individual length measurements were log-transformed (natural logarithm) and subjected to a generalized linear model (GLM) analysis (Nelder and Wedderburn, 1972). The test size (as the dependent variable) was regressed against the station (replication), sampling date, sampling depth, and the interaction term of sampling date and sampling depth as independent variables. As link function we used the identity for all species. The logtransformed length measurements for $T$. sacculifer were not normally distributed $(p<0.001)$, but it was clear from the histogram that the data follow a unimodal asymmetrical distribution, thus we used the gamma distribution for the GLM. All GLMs were tested using Spearman's rank-order correlation (Spearman, 1904) against their residuals, to evaluate their quality.

For the weight measurements we chose randomly 29 individuals of $T$. sacculifer without a sac-like chamber, and 27 individuals with a sac-like chamber from all samples. The weight was measured using a Sartorius SE 2 microbalance in order to investigate test mass differences throughout the sampling period. Together with measurements of the crosssectional area obtained with FIJI v. 1.47q (Schindelin et al., 2012), we calculated the area density $(A D=$ weight/area) of the specimens to constrain relative weight changes throughout the sampling interval, which may indicate the precipitation of gametogenic calcite (Bé, 1980).

Weight measurements were subjected to two additional analyses. For the first analysis, all raw weight data were plotted against the log-transformed cross-sectional area, and a linear regression (Eq. 1) was calculated for the data points. On the basis of this regression line we categorized the weight data into two categories: $1-$ weight $_{\text {(observed) }} \leq$ weight $_{\text {(calculated) }}$, and $2-$ weight $_{\text {(observed) }}>$ weight $_{(\text {calculated) }}$. With those two weight categories we could calculate the cross table with the respective date values and use a $\chi^{2}$ test of association to determine whether or not the relative occurrence of light and heavy individuals changed over the investigated time interval. For the second analysis we applied a GLM corresponding to the one described above on the $\mathrm{AD}$ instead of the length measurements, with identity as link function and based on the normal distribution $(p=0.162)$.

weight $_{(\text {calculated })}=0.0165 \times \log ($ area $)-0.1755$

\subsection{Analyses of stable isotopes}

Stable oxygen and carbon isotopes of the calcite tests $\left(\delta^{18} \mathrm{O}_{\mathrm{CALCITE}}\right.$ and $\left.\delta^{13} \mathrm{C}_{\mathrm{CALCITE}}\right)$ of living G. ruber (pink), with a similar test size of $>100 \mu \mathrm{m}$, were analyzed in order to study the isotope signal of living specimens from the water column and compare them to in situ environmental conditions (e.g., temperature). For each analysis, 4 to 10 individuals were taken from different samples (see the Supplement, Table S2). Prior to the measurements, the foraminifers were cracked to open the tests and to remove the remaining cytoplasm with a needle. The measurements were performed on a Thermo Scientific MAT 253 mass spectrometer equipped with a Kiel CARBO IV carbonate preparation device at GEOMAR. The stable isotope results are given relative to the Vienna Pee Dee Belemnite (V-PDB) in per mil $(\% o$ ) and calibrated versus the National Bureau of Standards (NBS) 19 . The reproducibility $( \pm 1 \sigma)$ of the in-house standard (Solnhofen limestone) is $<0.06 \%$ for $\delta^{18} \mathrm{O}$ and $<0.03 \%$ for $\delta^{13} \mathrm{C}$. Stable oxygen isotope values of the seawater $\left(\delta^{18} \mathrm{O}_{\text {SEAWATER }}\right)$ were measured on an isotope-ratio mass spectrometry (IRMS) at Hydroisotop GmbH (Schweitenkirchen). The results were reported in per mil (\%o) versus Vienna Standard Mean Ocean Water (VSMOW) and the analytic precision is $\pm 0.1 \%$ o $(1 \sigma) . \delta^{18} \mathrm{O}_{\text {EQUILIBRIUM }}$ was calculated after the $\delta^{18} \mathrm{O}$ temperature equation of Kim and O'Neil (1997) for inorganic precipitation with in situ temperatures recorded during the sampling campaign, and seawater values $\left(\delta^{18} \mathrm{O}_{\text {SEAWATER }}\right)$ scaled to PDB by subtracting $0.27 \%$ 。 (Hut, 1987).

\section{Results}

\subsection{Seawater properties during sampling}

Sea surface temperatures (SSTs) and sea surface salinities (SSSs) were measured in near-surface waters during the sampling campaigns in 1994, 1995, and 2012 (Fig. 2a). High SSS values were recorded in March 1995 and lowest values were measured in October/November 2012. In general, 
Table 2. Species collected during sampling period in 1994/1995 (Schmuker, 2000b) and in 2012 (this study). Relative abundance of each species from the total planktic or benthic assemblage is given for every sampling period. Taxonomy is according to Bé (1967) and Schiebel and Hemleben (2017). We distinguished the species based on morphogenetic studies following ${ }^{\mathrm{a}}$ Weiner et al. (2015), ${ }^{\mathrm{b}}$ Aurahs et al. (2011), ${ }^{c}$ André et al. (2013), ${ }^{d}$ Spezzaferri et al. (2015), and e Darling et al. (2009). Type references are from the Ellis and Messina (1940) catalogue.

\begin{tabular}{|c|c|c|c|}
\hline Species & $\begin{array}{r}\% \text { autumn } \\
1994\end{array}$ & $\begin{array}{r}\% \text { spring } \\
1995\end{array}$ & $\begin{array}{r}\% \text { autumn } \\
2012\end{array}$ \\
\hline \multicolumn{4}{|l|}{ Planktic foraminifers: } \\
\hline Globigerina bulloides & 0.04 & 0.23 & 0.16 \\
\hline Globigerinella calida ${ }^{\mathrm{a}}$ & 2.36 & 40.48 & 1.90 \\
\hline Neogloboquadrina dutertrei & 2.36 & 2.56 & 2.54 \\
\hline Globigerinita glutinata & 1.55 & 1.38 & 6.03 \\
\hline Globorotalia menardii & 6.51 & 3.93 & 1.43 \\
\hline Candeina nitida & & & 0.32 \\
\hline Pulleniatina obliquiloculata & & 0.06 & 0.05 \\
\hline Hastigerina pelagica & 0.34 & 1.17 & 0.42 \\
\hline Turborotalita quinqueloba & & & 0.53 \\
\hline Globigerinoides ruber (white) ${ }^{b}$ & 37.02 & 20.76 & 3.49 \\
\hline Globigerinoides ruber (pink) ${ }^{b}$ & 35.08 & 11.26 & 36.95 \\
\hline Globoturborotalita rubescens & 0.07 & 0.07 & 2.70 \\
\hline Trilobatus sacculifer syn. Globigerinoides sacculifer ${ }^{\mathrm{c}, \mathrm{d}}$ & 11.42 & 5.36 & 39.85 \\
\hline Globigerinella siphonifera $^{\mathrm{a}}$ & 1.59 & 5.91 & 1.59 \\
\hline Orbulina universa & 1.53 & 5.34 & 1.16 \\
\hline Globigerinoides conglobatus & 0.03 & 0.15 & \\
\hline Globorotalia truncatulinoides & 0.02 & 1.32 & \\
\hline Globorotalia hirsuta & 0.01 & & \\
\hline Neogloboquadrina pachyderma & & 0.03 & \\
\hline Globigerina falconensis & 0.06 & & \\
\hline Benthic foraminifers: & NA & NA & \\
\hline Asterigerina carinata & & & 0.38 \\
\hline Bolivina minima & & & 0.38 \\
\hline Bolivina paula & & & 0.38 \\
\hline Bolivina striatula & & & 0.38 \\
\hline Bolivina variabilis syn. Streptochilus globigerus ${ }^{\mathrm{e}}$ & & & 70.99 \\
\hline Cibicidoides pachyderma & & & 1.91 \\
\hline Cornuspira involvens & & & 0.38 \\
\hline Tretomphalus bulloides & & & 6.87 \\
\hline Trifarina bella & & & 17.56 \\
\hline
\end{tabular}

NA - not available.

the SST showed low values during early spring (March) and higher temperatures during autumn (September-November). Further, we note generally higher SSTs (around $1{ }^{\circ} \mathrm{C}$ ) in 2012 as compared to 1994 at the same locations (Figs. 1, $2 a)$. Stable oxygen isotope values of ambient surface water $\left(\delta^{18} \mathrm{O}_{\text {SEAWATER }}\right)$ ranged from $0.76 \%$ to $0.91 \%$ VSMOW (see the Supplement, Table S3). At the marine station of Isla Magueyes, an increased daily average wind speed (up to $\sim 12 \mathrm{~km} \mathrm{~h}^{-1}$ ) and a high daily precipitation (up to $\sim 70 \mathrm{~mm}$ ) were recorded in late October 2012, depicting the impact of the outer rainbands of hurricane Sandy (Fig. 3).

\subsection{Foraminiferal assemblage in plankton net hauls}

\subsubsection{Overview}

Fifteen living planktic foraminiferal species and nine benthic species were identified in the plankton net hauls at the different stations in 2012 (Table 2). The planktic assemblages are dominated by the tropical and subtropical species $G$. ruber (pink) and T. sacculifer, followed by Globigerinita glutinata. Bolivina variabilis dominates the floating benthic assemblage, while Tretomphalus bulloides, Trifarina bella and Cibicidoides pachyderma are common (Table 2).

The standing stock of the planktic foraminiferal assemblage varied highly from 0.2 to 131.6 ind. $\mathrm{m}^{-3}$ in single net hauls (Fig. 4). In 2012, the highest standing stock was ob- 


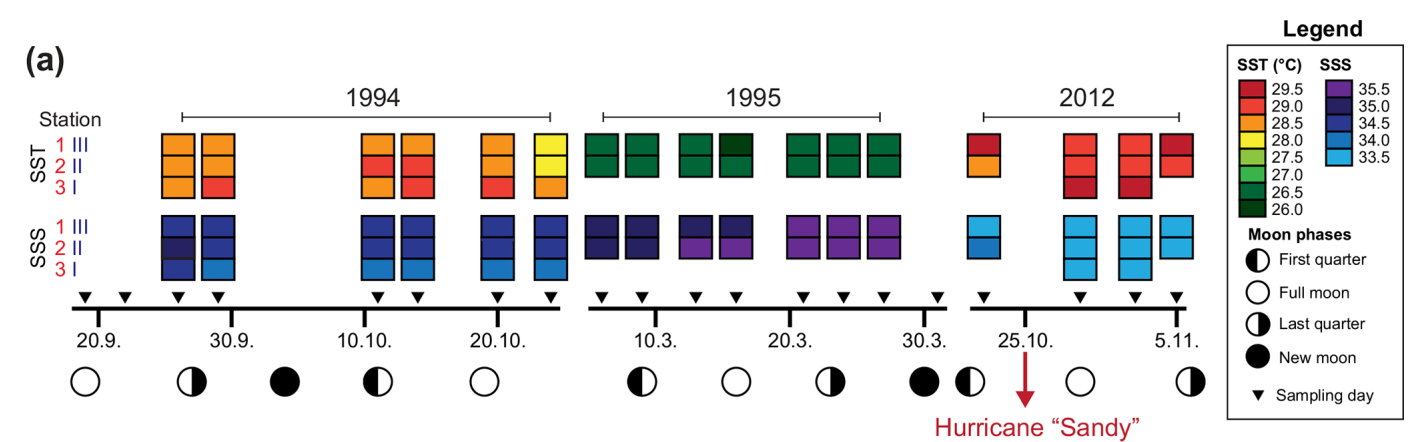

(b)

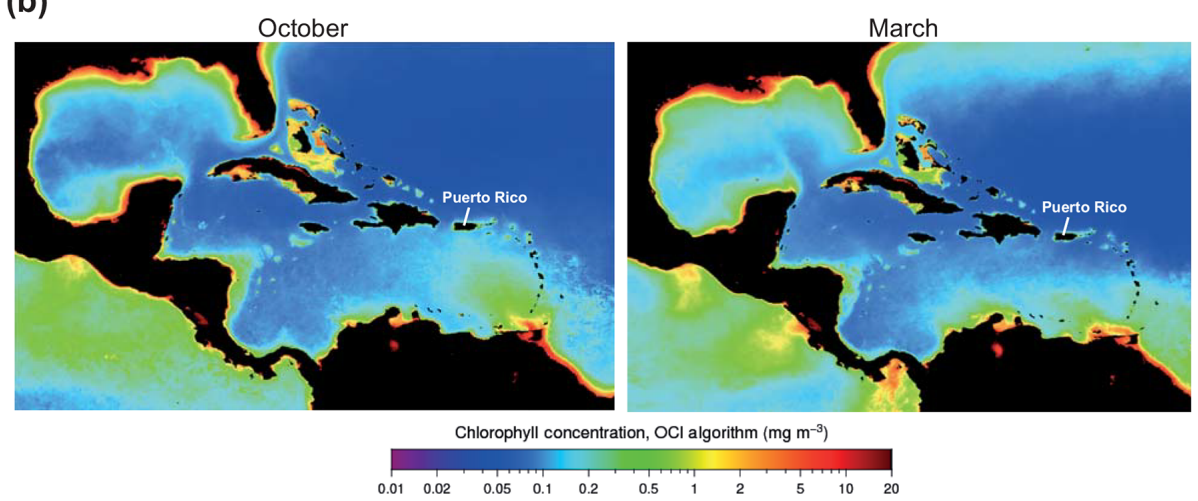

Figure 2. Hydrographical data in the study area. (a) Sea surface temperature (SST), sea surface salinity (SSS), and moon phases during the sampling campaigns in 1994/1995 (Schmuker, 2000b) and 2012 (this study, see the Supplement for data). Hurricane Sandy passed the Greater Antilles in late October 2012 (red arrow). (b) MODIS-Aqua monthly climatology chlorophyll concentration for October (2002-2018) and March (2003-2019). Images are derived from NASA Goddard Space Flight Center, Ocean Ecology Laboratory, Ocean Biology Processing Group (https://oceancolor.gsfc.nasa.gov/13/, last access: 8 October 2019).

served on 22 October. On 29 October, the standing stock was markedly lower in the upper sampling interval $(0-60 \mathrm{~m})$ and rose again thereafter (Fig. 4). Station 3 was sampled on 29 October and 2 November only. This station is on the shelf (Fig. 1) and showed the lowest standing stocks ( 0.59 and 3.15 ind. $\mathrm{m}^{-3}$, respectively) of all net samples. The abundance of benthic foraminifers varied from 0.3 to $\sim 21$ ind. $\mathrm{m}^{-3}$ in single net hauls (Fig. 4). A shift to a higher abundance of benthic specimens was observed concomitant with a decline of planktic foraminifers on the 29 October at stations 1 and 2 in the upper sampling interval. Even though the species composition did not show any significant differences between sampling days in 2012 (paired sample $t$ tests, $p>0.05$ ), different Bray-Curtis similarity indices can be observed across sampling days (Fig. 5, the Supplement, Table S4). The samples from 2 and 5 November have shown the highest similarity $(0.81)$. The sample from 22 October showed a lower similarity, and the sample from the 29 October was most different (0.36) from the assemblages on the other sampling days in 2012. The sampling season (autumn or spring) and the sampling year (1994/1995 or 2012) showed a significant relationship $(p=0.001)$ with the observed changes in the foraminiferal assemblage (Fig. 6a). While the analyses imply that a spring assemblage and an au- tumn assemblage of planktic foraminifers can be clearly distinguished, it also indicates a long-term assemblage change. From autumn 1994 to 2012 we observe a decrease in the relative abundance of $G$. ruber (white) and an increase in the relative abundance of T. sacculifer (Fig. 6, Table 2).

\subsubsection{Depth distribution pattern of foraminifers}

In order to test whether habitat depths of different species depend on the water masses, two depth intervals (0-60 and $60-100 \mathrm{~m}$ ) were sampled at stations 1 and 2 in 2012 . The highest average standing stock of living planktic foraminifers was found in the upper interval (Fig. 4). Differences in the assemblage composition between the upper and the lower interval were limited to rare species (Fig. 6b). Station 1 had a slightly higher standing stock in the upper interval than station 2, although both stations showed a profound abundance fluctuation during the sampling time. This variability was not recognized in the deeper intervals (Fig. 4). In the upper part of the water column, G. ruber (pink), T. sacculifer, and G. glutinata dominated the assemblages (Fig. 6b). Among the common species, G. ruber (white) and Globoturborotalita rubescens showed the highest abundance in the upper interval too. Higher abundances in the deeper interval are observed for Globorotalia menardii, Globigerinella calida, 


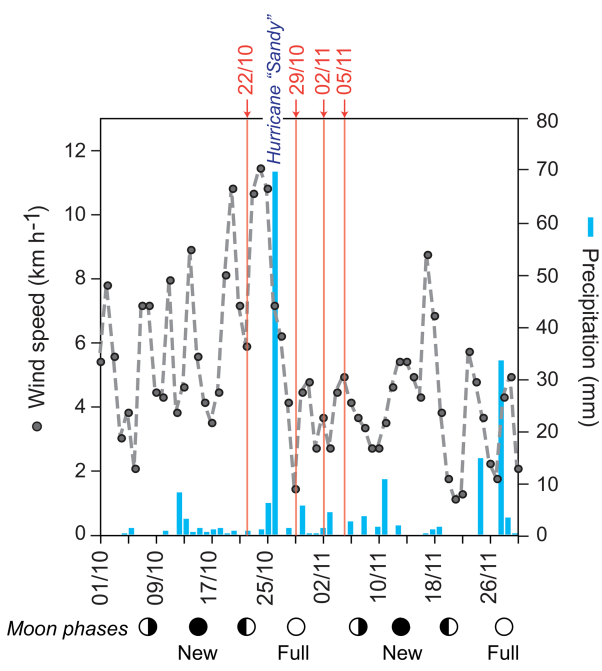

Figure 3. Wind speed and precipitation record during October and November 2012 recorded by the Bio-Optical Oceanography Laboratory at the field station at Isla Magueyes, La Parguera (University of Puerto Rico, Mayagüez Campus (UPRM); http://bio-optics. uprm.edu, last access: 12 December 2018). Grey dots and dashed line: average daily wind speed $\left(\mathrm{km} \mathrm{h}^{-1}\right)$; blue bars: daily precipitation (mm); red numbers indicate the sampling dates (day/month) in 2012; circles indicate the moon phases. Hurricane Sandy passed the Greater Antilles in late October 2012.

Globigerinella siphonifera, and Orbulina universa (Figs. 4, 6b).

The highest abundance of benthic species was recorded at station 2 on the first sampling day in the lower depth interval (60-100 m, Fig. 4), mainly due to a high number of Trifarina bella. On the 29 October, higher abundances of benthic foraminifers were found in the upper interval at both stations. This was mainly caused by the exceptionally high abundance of B. variabilis (Fig. 4). On the 2 and 5 November 2012, the upper interval at station 2 also had a high standing stock of $B$. variabilis. Station 1 yielded benthic specimens on the 29 October and 2 November only. Rare Bolivina species, Asterigerina carinata and Cornuspira involvens, were collected on the 29 October. Cibicidoides pachyderma was found in several net samples and showed no distinctive pattern over time or space.

\subsection{Analyses of size and weight of Trilobatus sacculifer}

Size and weight changes of $T$. sacculifer individuals were investigated along the sampling period of 2 weeks. A slight increase in size of $125 \mu \mathrm{m}$ of the individuals was recognized within the 2 weeks (Fig. 7a, b). This change in shell length over time is statistically significant as shown by the GLM (Table 3). The size difference between the individuals of stations 1 and 2 is statistically not significant (Table 3 ), indicating that the sampling was representative for the waters south of Puerto Rico. Individuals occurring above $60 \mathrm{~m}$ water depth
Table 3. Results of the generalized linear model (link function: identity, gamma distribution) approach to analyze the statistical significance of size changes of Trilobatus sacculifer $(n=655)$ as a function of station (replicate), sampling date, sampling depth, and the interaction between sampling date and sampling depth.

\begin{tabular}{lrrr}
\hline Source & \multicolumn{3}{c}{ Type III linear regression } \\
\cline { 2 - 4 } & Wald chi-square test & df & Sig. \\
\hline (Intercept) & 51719.448 & 1 & $<0.001$ \\
Sampling station & 0.803 & 1 & 0.344 \\
Sampling date & 42.490 & 3 & $<0.001$ \\
Sampling depth & 6.723 & 1 & 0.004 \\
date $*$ depth & 2.072 & 3 & 0.393 \\
\hline
\end{tabular}

were smaller than specimens from below $60 \mathrm{~m}$ water depth. Although a size difference between the two depth intervals is statistically significant, the interaction term of sampling date and depth showed no significant influence on the size of individuals of T. sacculifer (Table 3 ). This means, that at each date sampled we found a majority of big, mature individuals in the deep sampling interval, but there was no migration of these individuals in the water column throughout our sampling period.

Regarding the weight measurements, we observed a trend with heavier (higher AD) individuals in the deep sampling interval (Fig. 7c, Table 4), but a change of weight over time is not significant in a GLM (Table 4). This is corroborated by the $\chi^{2}$ test of association, which showed no significant change in the frequency of light and heavy specimens over the investigated time interval $\left(\chi^{2}=1.031, \mathrm{df}=2\right.$, $p=0.597)$. The interaction term of sampling date and depth showed no significant influence on the weight of specimens of $T$. sacculifer. Yet, we found fewer individuals of $T$. sacculifer with a sac-like last chamber at the first two sampling days than at the later dates, a fact that might influence the accuracy of the results. There is no detectable correlation between the GLM's predicted values and their residuals $(p=0.859)$, indicating an effective detrending of the data. Individuals of $T$. sacculifer without a sac-like last chamber (trilobus-morphotype) are on average lighter than individuals with the sac (Fig. 7d).

\subsection{Stable isotopes of Globigerinoides ruber (pink) and ambient seawater}

The stable oxygen isotopes $\left(\delta^{18} \mathrm{O}_{\mathrm{CALCITE}}\right)$ of $G$. ruber (pink) averaged $-2.54 \%$ and the stable carbon isotopes $\left(\delta^{13} \mathrm{C}_{\text {CALCITE }}\right)$ averaged $0.49 \%$. Samples of the deeper net $\left(60-100 \mathrm{~m}\right.$ water depth) yielded higher $\delta^{18} \mathrm{O}_{\mathrm{CALCITE}}$ $\left(-2.4 \%\right.$ ) and higher $\delta^{13} \mathrm{C}_{\mathrm{CALCITE}}$ values $(0.65 \%$ ) than samples of the upper water mass $\left(\delta^{18} \mathrm{O}=-2.62 \% ; \delta^{13} \mathrm{C}=\right.$ $0.38 \%$; Fig. 8). The lowest $\delta^{13} \mathrm{C}_{\text {CALCITE values were mea- }}$ sured in individuals collected on the 29 October 2012. 
(a)

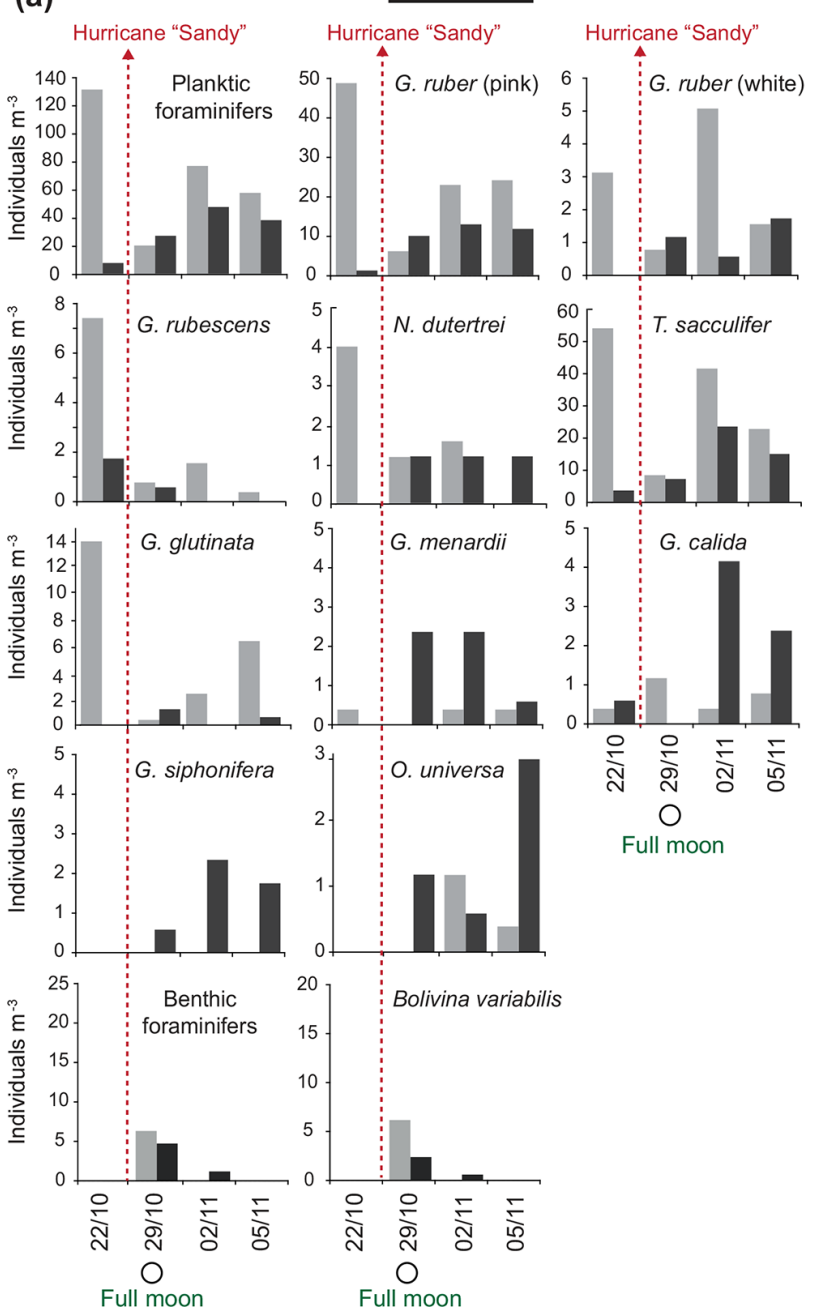

(b)
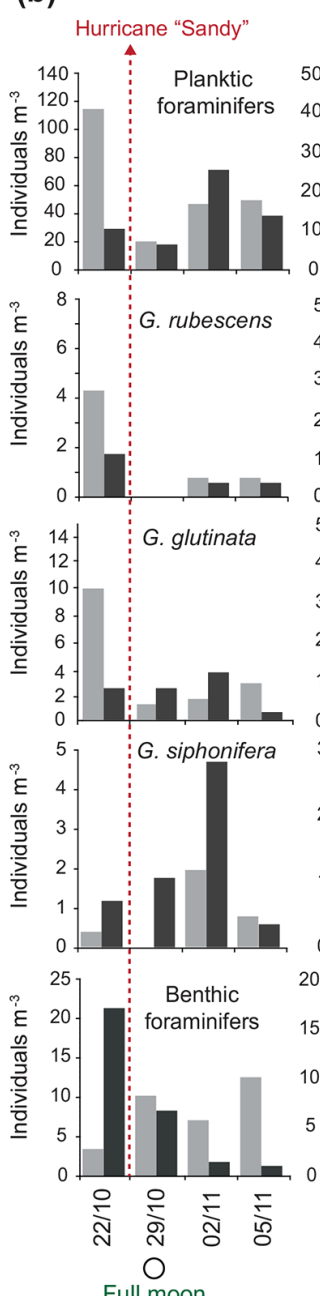

Full moon
Station 2
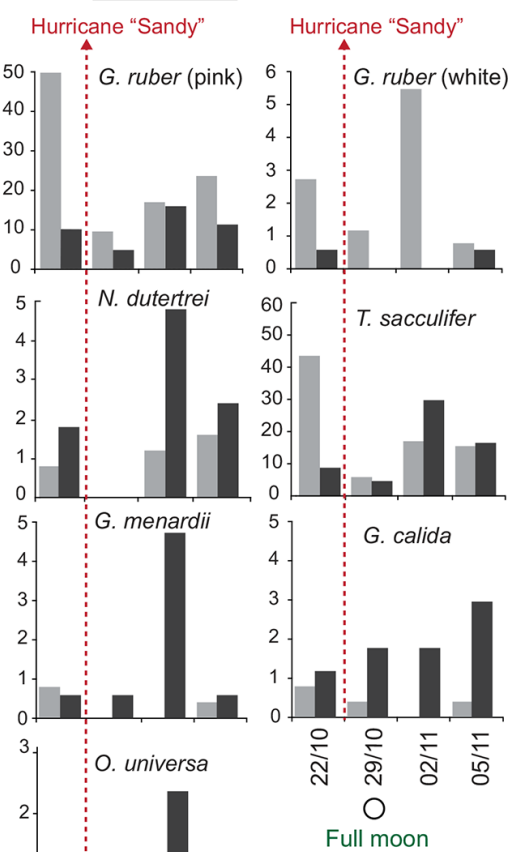

Figure 4. Foraminiferal abundance (individuals per $\mathrm{m}^{3}$ seawater) at station 1 (a) and station 2 (b) of the upper (0-60 m; light grey bars) and deeper (60-100 m; dark grey bars) sampling intervals in 2012. Hurricane Sandy is marked by dashed red arrows.

Table 4. Results of the generalized linear model (link function: identity, normal distribution) approach to analyze the statistical significance of $\mathrm{AD}$ changes of Trilobatus sacculifer with a sac-like chamber ( $n=27$ ) as a function of station (replicate), sampling date, sampling depth, and the interaction between sampling date and sampling depth.

\begin{tabular}{lrrr}
\hline Source & \multicolumn{3}{c}{ Type III linear regression } \\
\cline { 2 - 4 } & Wald chi-square test & df & Sig. \\
\hline (Intercept) & 795.553 & 1 & $<0.001$ \\
Sampling station & 0.024 & 1 & 0.876 \\
Sampling date & 4.618 & 2 & 0.099 \\
Sampling depth & 5.830 & 1 & 0.016 \\
date $*$ depth & 0.784 & 1 & 0.376 \\
\hline
\end{tabular}

Individuals sampled at station 3 showed the lowest stable isotope values $\left(-2.96 \%\right.$ or $\delta^{18} \mathrm{O}_{\mathrm{CALCITE}}$ and $-0.4 \%$ o for $\delta^{13} \mathrm{C}_{\text {CALCITE}}$ ). The equilibrium value of the seawater $\left(\delta^{18} \mathrm{O}_{\text {EQUILIBRIUM }}\right)$ averaged $-2.13 \pm 0.07 \%$, indicating the predicted inorganic calcite value precipitated in thermodynamic equilibrium with ambient seawater temperature and $\delta^{18} \mathrm{O}_{\text {SEAWATER }}$ (Fig. 8).

\section{Discussion}

\subsection{Seasonal response and interannual variation of planktic foraminifers}

Previous studies revealed that the distribution and community composition of planktic foraminifers from the Caribbean Sea are generally influenced by biological and environmental factors, as well as geographical settings (e.g., Jones, 1968, 1971; Schmuker, 2000a; Schmuker and Schiebel, 2002; 


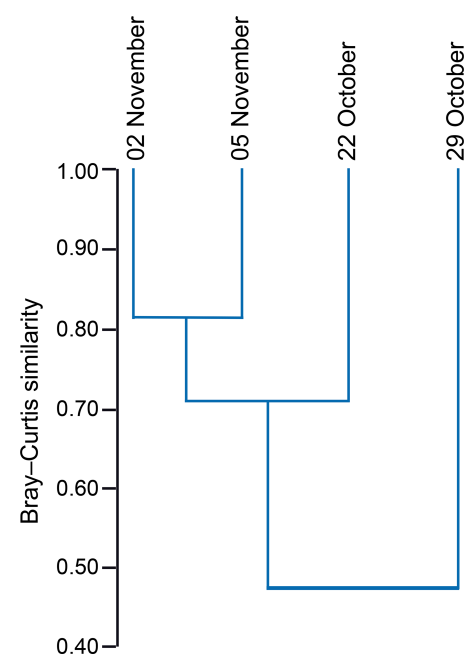

Figure 5. Hierarchical cluster analysis showing the similarity of foraminiferal assemblages from station 1 and station 2 between different sampling days (day/month) in 2012. Cluster analysis was performed using the unweighted pair group method with arithmetic mean (UPGMA) based on the Bray-Curtis similarity index (values from 0 to $1 ; 1$ indicates the highest similarity between the faunas).

Tedesco et al., 2009; Spear et al., 2011; Poore et al., 2013; Jentzen et al., 2018b). Our planktic foraminiferal composition of Puerto Rico comprises common surface dwellers for the study area and surrounding basins (e.g., T. sacculifer, G. ruber (pink and white), G. glutinata; Jones, 1968; Bé et al., 1971; Schmuker and Schiebel, 2002; Tedesco and Thunell, 2003; Jentzen et al., 2018b). Furthermore, our data from autumn 2012 show a similar species inventory as described in 1994 for the same area, and the autumn assemblage of our survey in 2012 is closer to the autumn assemblage in 1994 of Schmuker (2000b) than to their spring assemblage in 1995 (Fig. 6a, Table 2). In spring 1995, Globigerinella calida, Globigerinella siphonifera, Orbulina universa, Hastigerina pelagica, and Globorotalia truncatulinoides were common, whereas the autumn assemblage in 1994 mainly comprised Globigerinoides ruber (pink and white), Trilobatus sacculifer, Globorotalia menardii, Neogloboquadrina dutertrei, and Globigerinita glutinata (Fig. 6c). In our survey from autumn $2012, T$. sacculifer $(\sim 40 \%$ of the total planktic assemblage) and G. ruber (pink) $(\sim 37 \%)$ were the dominant species. Species of the spring assemblage by Schmuker (2000b) were, with the exception of G. truncatulinoides, also found in the samples from 2012, but they occurred in low numbers and mainly in the deeper interval (Fig. 6b). Schmuker (2000b) sampled the upper $10 \mathrm{~m}$ of the water column and from the surface to $120 \mathrm{~m}$ water in one haul, thus a change of the habitat depths of the species during different seasons was not resolved. Even though the capability of planktic foraminifers to perform fast, diurnal vertical migrations or buoyancy changes are unlikely (Harbers, 2011; Siccha et al., 2012; Meilland et al., 2019), we speculate about the existence of a seasonal change in species-specific habitat depths, probably facilitated by a variable seasonal hydrography and thermocline depth changes (see Schmuker, 2000b; Rebotim et al., 2017). Our data from 2012 indicate preferred habitats of certain species, although the dominant faunal elements, G. ruber (pink) and T. sacculifer, were found in high numbers in the entire sampled water column (up to $80 \%$ together of the total planktic assemblage, Fig. 6b). Both species are common in tropical and subtropical oceans, and they are frequent in the Caribbean Sea (Jones, 1968; Bé et al., 1971; Schmuker and Schiebel, 2002; Jentzen et al., 2018b). The species G. ruber (pink) and G. glutinata indicate a high nutrient supply (e.g., Bé and Tolderlund, 1971; Schiebel et al., 2001; Retailleau et al., 2011). A high nutrient flux into the Caribbean Sea during autumn is likely caused by the riverine plumes of the Amazon and Orinoco rivers (Fig. 2b; Bidigare et al., 1993; Corredor and Morell, 2001; Chérubin and Richardson, 2007).

Higher abundances of G. calida, G. siphonifera, N. dutertrei, and $G$. menardii in the deep sampling interval (Fig. 4) point to a change in the character of the foraminiferal habitat below $60 \mathrm{~m}$. The species G. calida and G. siphonifera show variable depth habitats in the Atlantic and Caribbean Sea and may live above, in, and below the pycnocline (Rebotim et al., 2017; Jentzen et al., 2018b). Globigerinella calida is linked to oligotrophic conditions during spring in the Caribbean Sea off Puerto Rico (Schmuker, 2000b), and is associated with neritic conditions in the upwelling area of the Bay of Biscay (Retailleau et al., 2012). Based on oxygen isotope $\left(\delta^{18} \mathrm{O}\right)$ data, $N$. dutertrei and G. menardii are known to dwell in the seasonal pycnocline (Tedesco et al., 2007; Steph et al., 2009); however, plankton tows from the Caribbean Sea (foraminiferal census and $\delta^{18} \mathrm{O}$ data) indicate that juvenile specimens live in the mixed layer before they sink to deeper waters and continue calcifying (Jentzen et al., 2018a, b). Even though, in our plankton tows in 2012, only small numbers of the abovementioned species were collected $\left(<5\right.$ ind. $\mathrm{m}^{-3}$; Fig. 4$)$, the change in the composition of rare species with preferred habitats in the pycnocline most likely indicates the influence of the SUW, and thus a change of the food source and light availability.

A slight but conspicuous change of the foraminiferal assemblage composition took place between 1994 and 2012. In autumn 1994, G. ruber (white) had a substantially higher percentage (37\%) than in $2012(3.5 \%)$, resulting in a high G. ruber pink-to-white ratio of 10.3 in 2012, compared to a low ratio of 0.8 in 1994 (Fig. 6, Table 2). A decline of G. ruber (white) during the last decade has previously been observed in the Caribbean Sea (Jentzen et al., 2018b) and in the tropical Atlantic (Harbers, 2011). Furthermore, variable abundances of $G$. ruber (white) were observed in sediment traps of the Gulf of Mexico, with low numbers in 2008 and 2009 supporting the trend of a decreasing abundance but also indicating a high variability (Poore et al., 2013). Jentzen et al. (2018b) related the low numbers of $G$. ruber 

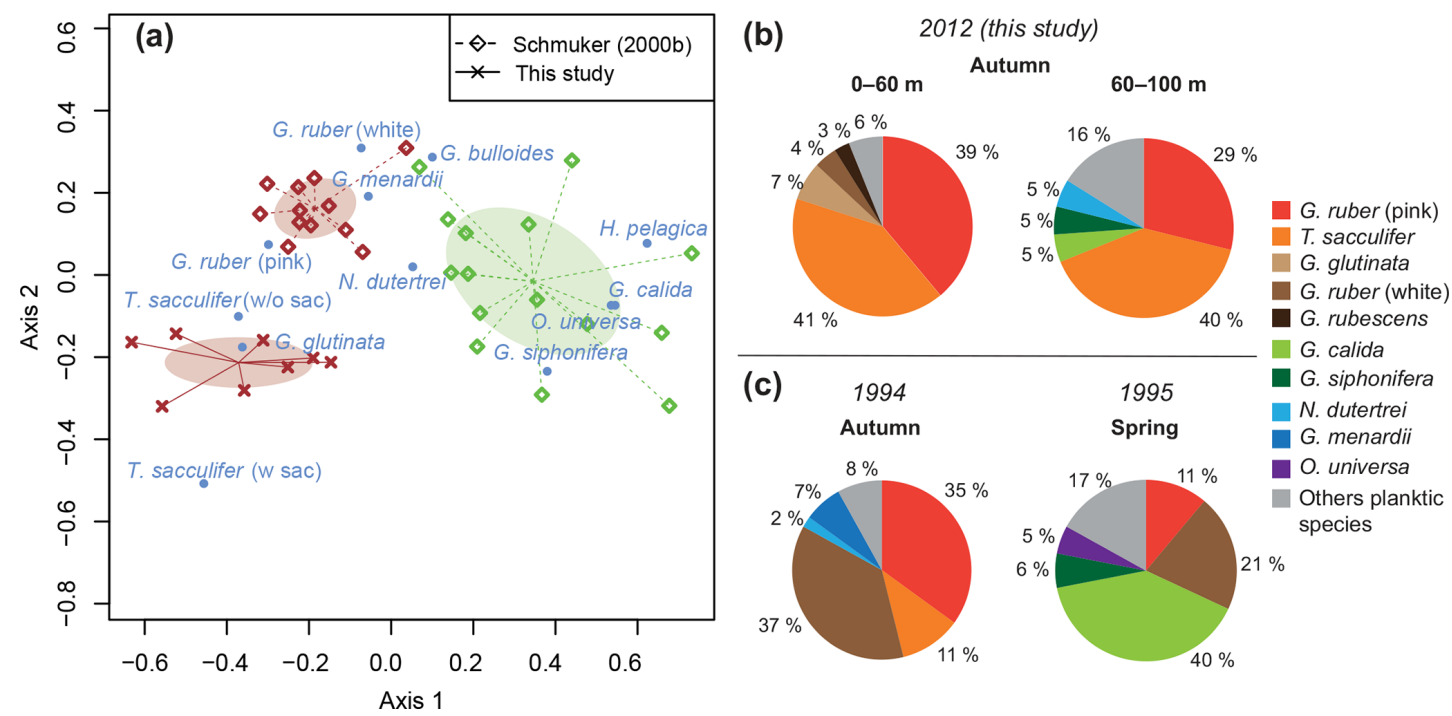

Figure 6. Comparison of planktic foraminiferal assemblages between spring (1995) and autumn (1994, 2012). (a) Optimal NMDS ordination (Wisconsin double-standardized relative abundances, Bray-Curtis similarity index) of planktic foraminifers during spring (green) and autumn (brown) 1994/1995 (Schmuker, 2000b), and autumn 2012 (this study). Ellipses indicate standard deviation of assemblages around the centroid of the groups. (b) Average assemblage composition of planktic foraminifers at stations 1 and 2 in 2012. Percentages were calculated from the total living planktic assemblage of the sampling intervals 0-60 and 60-100 m water depths. (c) Average assemblage composition of planktic foraminifers from autumn 1994 and spring 1995, mesh size $>150 \mu$ m (Schmuker, 2000b).

(white) and the higher pink-to-white ratio (up to 6 in the eastern Caribbean Sea) to increasing SSTs over the past decades and changes in nutrient flux and primary production, rather than to seasonal variations or local, short-term, and/or spatial variability (patchiness in time and space). Our data collected south of Puerto Rico show higher SSTs in autumn 2012 compared to the year 1994 (average increase of $1{ }^{\circ} \mathrm{C}$ ). These data support the contention that the observed faunal change in the foraminiferal assemblages can be linked to increasing SST; nevertheless, patchiness and drifting of planktic foraminifers can result in variable abundances of planktic foraminifers in the water column (e.g., Siccha et al., 2012).

\subsection{The influence of the shelf and benthic species}

The near-shore station 3 showed distinctively low numbers of foraminifers (average $1.69 \mathrm{ind} . \mathrm{m}^{-3}$ ). The difference of station 3 to the other stations could partially be due to a different way of sampling (only in $\pm 5 \mathrm{~m}$ water depth). However, low abundances of planktic foraminifers close to the coast and in shallow waters have been observed before, e.g., in the Bay of Biscay (Retailleau et al., 2009) and in the Santaren Channel between the Bahamas and Cuba (Jentzen et al., 2018b). In the Bay of Biscay, freshwater input has been suggested as a factor influencing the foraminiferal assemblage. In the Santaren Channel, the low abundance of living planktic foraminifers has been suggested as consequence of the prevailing neritic conditions at shallow water depths $(>530 \mathrm{~m})$, which most likely inhibits the reproduction of planktic foraminifers and chance of survival. The abundance of benthic foraminifers in the water column in 2012 off Puerto Rico was lower than previously reported by Fornshell (2005) from plankton hauls in the vicinity of reefs around Puerto Rico. Nonetheless, the abundances were similar to numbers in autumn 1994 as reported by Schmuker (2000b). In the benthic assemblage of 2012, meroplanktic species (such as Tretomphalus bulloides) were common in the plankton nets. This species builds a floating chamber in the late stage of its life cycle to release gametes in the upper water column (Sliter, 1965; RückertHilbig, 1983; see SEM image of the floating chamber in the Supplement, Fig. S4). A high relative abundance of living individuals of the biserial Bolivina variabilis (Streptochilus globigerus) was observed in the nets as well (Table 2). This species was found in plankton tows from the Caribbean Sea and northern Atlantic (Hemleben et al., 1989; Schmuker and Schiebel, 2002; Jentzen et al., 2018b), but it was either absent or rare in near-shore surface sediments off southern Puerto Rico (Brooks, 1973; Seiglie, 1975). Bolivina variabilis grows and calcifies in both a planktic and benthic habitat (tychopelagic lifestyle) (Darling et al., 2009; Kučera et al., 2017). Kučera et al. (2017) suggested that the tychopelagic mode of life of Bolivina/Streptochilus mirrors the transition process from a benthic to a holoplanktic lifestyle that has been performed several times during Earth's history. After 29 October 2012, the abundance of B. variabilis increased and was higher in the uppermost $60 \mathrm{~m}$ of the water column than at depths below (Fig. 4). It is conceivable that $B$. variabilis was swept into the water column by wave action during the stormy weather conditions of hurricane Sandy. Thus, we 

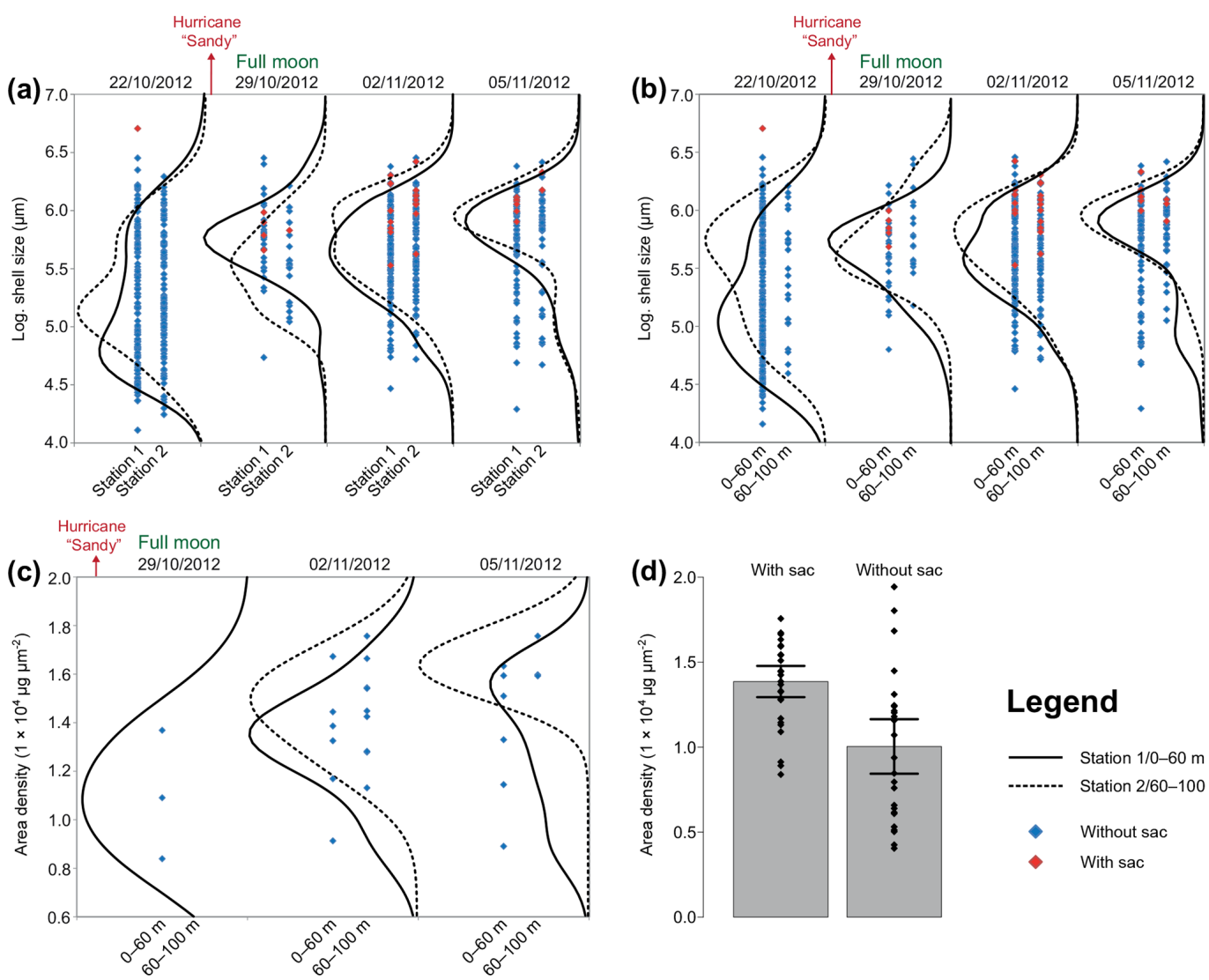

\section{Legend}

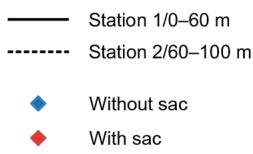

With sac

Figure 7. Size and area density changes of Trilobatus sacculifer in autumn 2012. The data are log-transformed (a, b) across the sampling period in 2012 at stations 1 and 2 and different depth intervals. A full moon occurred on the second sampling day, 29 October 2012. Hurricane Sandy passed the Greater Antilles in late October 2012. (a) Logarithmic sizes of T. sacculifer (red symbols indicate individuals with a sac-like chamber, and blue symbols indicate individuals without a sac-like chamber) at two different stations (1 and 2), pooled over the complete depth range from 0 to $100 \mathrm{~m}$. Black lines show kernel density distributions of sizes at station 1 (solid) and station 2 (dashed). (b) Logarithmic sizes of T. sacculifer (red symbols indicate individuals with a sac-like chamber and blue symbols indicate individuals without a sac-like chamber) at two different depth intervals, pooled over stations 1 and 2. Black lines show kernel density distributions for depth of 0-60 m (solid) and depth 60-100 m (dashed). (c) Area density (AD) of T. sacculifer (with sac-like chamber) along the sampling period sampled at two different depth intervals, pooled over stations 1 and 2. Black lines show kernel density distributions of weights at a depth of 0-60 m (solid) and at a depth of 60-100 m (dashed). (d) Comparison of AD between T. sacculifer with sac-like chamber and without sac-like chamber. Grey bars depict the mean AD including $95 \%$ confidence interval as error bars.

assume that this species thrived suspended in the upper water column, pursuing a part of their planktic lifestyle during the days after the hurricane. The empty tests of other benthic species (e.g., Trifarina bella) collected in the water column have probably been eroded from the surface sediments or brought in suspension, attached to seagrass, and were transported further offshore (Loose, 1970; Murray, 1987; Schmuker, 2000b; Fornshell, 2005).

\subsection{Lunar reproductive cycle}

Our dataset facilitated the investigation of synchronized size changes of $T$. sacculifer through time, which could indicate reproduction cycles. Trilobatus sacculifer was reported to have a lunar reproduction cycle, based on observations from plankton net samples (Almogi-Labin, 1984; Bijma et al., 1990; Erez et al., 1991; Jentzen et al., 2018b). The individuals reproduced preferentially at full moon and underwent a migration from the surface to deeper waters, near the seasonal thermocline (e.g., Erez et al., 1991). The formation of a sac-like final chamber, which is diagnostic for $T$. sacculifer, was described to be associated with the onset of reproduction. The release of gametes will take place around 24-48 $\mathrm{h}$ after the sac-like chamber formation (Bé, 1980). Yet, other factors such as environmental stress (e.g., by salinity changes) can influence the morphology of $T$. sacculifer as well (Weinkauf et al., 2019). Nevertheless, we expected that the number of individuals of $T$. sacculifer with a sac-like chamber should be highest before full moon and drop significantly afterwards, as observed in the Red Sea (Erez et al., 1991). In contrast to these observations, we found most in- 


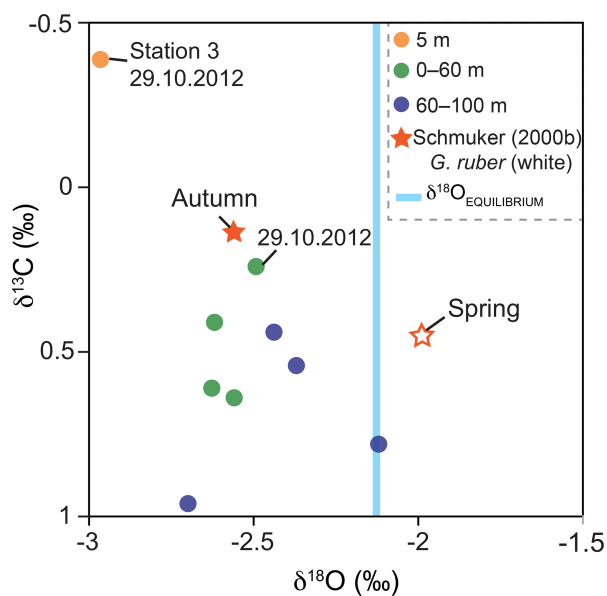

Figure 8. Stable oxygen and carbon isotope values of G. ruber (pink) and average $\delta^{18} \mathrm{O}_{\text {EQUILIBRIUM value of ambient surface }}$ water. Green and blue dots indicate the average values of stations 1 and 2 from the four sampling days and two sampling depth intervals in 2012 (this study). Stars indicate the isotope data of Schmuker (2000b) from G. ruber (white) collected in autumn 1994 and spring 1995. Orange dot: stable isotope value of individuals collected at station 3 on the 29 October 2012 (this study). Note: hurricane Sandy passed the Greater Antilles in late October 2012 resulting in high $\delta^{13} \mathrm{C}_{\mathrm{CALCITE}}$ values on 29 October in the mixed layer.

dividuals with a sac-like chamber at the third day after full moon and hardly any before (Fig. 7c). Test sizes in $T$. sacculifer appeared to have increased with time, which by itself is indicative of the existence of a growth cohort (Fig. 7a, b). Yet, the size does not peak at full moon, the population continues to grow and thicken for $7 \mathrm{~d}$ after the full moon, although the change was not significant. Therefore, the size increase of $T$. sacculifer over time did not seem to be related to reproduction synchronized with the full moon. Our data also do not support evidence for migration of $T$. sacculifer in the water column throughout its reproductive cycle. Both size data and weight data show the biggest individuals dwelling in the deeper sampling interval independent of the sampling day (Fig. 7b, c). The comparison of the area density of T. sacculifer confirms that the development of the sac-like chamber is associated with heavier calcification, probably indicating gametogenic calcification (e.g., Bé, 1980), and such individuals might be close to reproduction (Fig. 7d).

\subsection{Stable oxygen isotope signal}

In the upper water column, stable oxygen isotope values of G. ruber (pink) show an offset of $-0.46 \%$ o to the equilibrium values of ambient seawater (Fig. 8). As the species G. ruber (pink) hosts symbionts, this offset possibly indicates photosymbiont activity (e.g., Kahn, 1979; Erez and Honjo, 1981). Symbiont activity lowers the stable oxygen isotope composition of calcite tests (Spero and Lea, 1993) and high negative disequilibrium values (up to $-0.35 \%$ ) in symbiont-bearing species (e.g., O. universa and T. sacculifer) were observed before in living foraminifers in the Caribbean Sea (Jentzen et al., 2018a). Off the coast of Puerto Rico, $\delta^{18} \mathrm{O}_{\text {CALCITE }}$ values from autumn 1994 (Schmuker, 2000b) of G. ruber (white) yield the same average values as G. ruber (pink) in $2012(-2.5 \%$ ) and are lower than in spring 1995. Based on the sediment trap study of Richey et al. (2019), no discernable difference can be determined in $\delta^{18} \mathrm{O}_{\text {CALCITE }}$ between the chromotypes G. ruber (white) and (pink) from individuals co-occurring in the Gulf of Mexico. For this reason, we assume that the seasonal isotope signal overprints any species-specific bias of the two chromotypes, which thus can be compared to each other. Applying the $\delta^{18} \mathrm{O}$ paleotemperature equations for $G$. ruber (pink) of Farmer et al. $\left(2007 ; 4.86^{\circ} \mathrm{C} \% o^{-1}\right.$, calibration error (standard deviation $\sigma$ ) of $0.24 \%$ ), specimens of the upper $60 \mathrm{~m}$ of the water column in 2012 yield average $\delta^{18} \mathrm{O}$ temperatures of $\sim 29.5^{\circ} \mathrm{C}$, which are in the range of the average measured in situ temperatures of $\sim 29.2^{\circ} \mathrm{C}$. Below $60 \mathrm{~m}$ water depth, the living individuals yield on average higher $\delta^{18} \mathrm{O}_{\mathrm{CALCITE}}$ values $(+0.17 \%$ ) , which likely depict the properties of the SUW (lower temperature and higher salinity than shallower waters), and thus corroborates that G. ruber (pink) calcifies over a broad depth range within the upper water column (i.e., $0-100$ m; Fig. 8).

\subsection{Hurricane Sandy}

Hurricane Sandy, which passed the Greater Antilles on 24 October 2012, induced higher waves and precipitation at the sampling site off Puerto Rico (Fig. 3), and thereby most likely affected the foraminiferal assemblage. After hurricane Sandy, the planktic foraminiferal abundance in the upper water column was much lower on 29 October when next sampled and at the same time, a higher number of living benthic species (B. variabilis) was found (Fig. 4). Other factors such as patchiness and drifting of living planktic foraminifers can vary the abundance in the water column as well (e.g., Siccha et al., 2012). However, Schiebel et al. (1995) have described the influence of two storms with wind speeds up to 12 on the Beaufort scale on living planktic foraminiferal assemblages in the North East Atlantic Ocean. They affected the mixed layer and the total abundance of small specimens was higher afterwards. The storm events raised the nutrient and chlorophyll concentrations in the mixed layer and thereby pushed the reproduction. An elevated chlorophyll concentration after hurricanes was reported from the Sargasso Sea (Babin et al., 2004) and from Puerto Rico after hurricane Georges in 1998 (Gilbes et al., 2001). A higher chlorophyll concentration was measured $3 \mathrm{~d}$ after hurricane Georges had crossed the island. Additionally, a higher rainfall and river runoff with terrestrial load was observed, which affected neritic environments after the storm. Even though, the measured wind speed was low on Puerto Rico in late October 2012 com- 
pared to the hurricane in 1998, intense precipitation and extensive flooding were recorded during the passage of hurricane Sandy (Fig. 3; Blake et al., 2013). A higher nutrient input in combination with terrestrial runoff might have contributed to a higher turbidity in the water column close to the coast and most likely to a lower $\delta^{13} \mathrm{C}_{\text {DIC }}$ signature in the seawater (Ravelo and Hillaire-Marcel, 2007; Zhao et al., 2015). If this was the case, the living conditions changed for a short time and may have affected the planktic assemblage observed within this study. On the 29 October, low $\delta^{13} \mathrm{C}_{\text {CALCITE val- }}$ ues of G. ruber (pink), collected in the upper water column and at station 3, probably recorded the storm event (Fig. 8). Symbiont photosynthetic activity can strongly influence the incorporation of $\delta^{13} \mathrm{C}$ in foraminiferal tests (Spero and DeNiro, 1987; Spero and Williams, 1988; Spero and Lea, 1993). The studies showed that during lower light irradiance, foraminiferal calcite is depleted in $\delta^{13} \mathrm{C}_{\mathrm{CALCITE}}$, as observed in our study. Lin et al. $(2004,2011)$ indicated depleted $\delta^{13} \mathrm{C}_{\text {CALCITE }}$ in foraminiferal tests in relation to high nutrient concentrations and supply of ${ }^{12} \mathrm{C}$-rich water in the South China Sea. Based on those observations we conclude that the vicinity of the coast has influenced the station on the shelf break. The data support the assumption of a higher terrestrial runoff and higher turbidity after the hurricane, which may have caused lower irradiance light levels, reduced photosymbiont activity, and lower $\delta^{13} \mathrm{C}_{\mathrm{DIC}}$ of the seawater, hence lowered $\delta^{13} \mathrm{C}_{\mathrm{CALCITE}}$ values in the mixed layer.

\section{Summary and conclusion}

Depth-stratified replicated plankton net sampling off Puerto Rico in autumn 2012, revisiting three stations previously sampled in autumn 1994 and spring 1995, denotes that the foraminiferal assemblage in autumn 2012 was largely similar to the autumn assemblage in 1994, although a decline of G. ruber (white) in 2012 was observed off the coast of Puerto Rico. This decline might indicate a change of environmental factors such as increasing SST during the last decades. Below $60 \mathrm{~m}$ water depth, the assemblage composition was different than at the surface, the first specimens of deep-dwelling species emerged and $\delta^{18} \mathrm{O}_{\mathrm{CALCITE}}$ values indicate the influence of the SUW. Test size and weight measurements of T. sacculifer indicate no synchronization of the reproduction linked to the lunar cycle; nonetheless, T. sacculifer were continuously growing during the sampling time. Hurricane Sandy passed the Greater Antilles during the sampling period in 2012 and affected the planktic foraminiferal assemblage. The storm most likely triggered a decrease in the standing stock and depleted $\delta^{13} \mathrm{C}_{\mathrm{CALCITE}}$ values in the upper water column as a result of a higher turbidity and terrestrial runoff after the storm and the vicinity of the coast. The exact mechanism by which stormy weather and heavy rainfall may affect the foraminiferal assemblage is beyond the scope of the present study; nonetheless, it should be considered that such tropical cyclones may perturb the plankton assemblage, and hence make it even more difficult to decipher the factors controlling living planktic foraminifers on a small spatiotemporal scale.

Data availability. The dataset of this article can be found in the Supplement and in Schmuker (2000b).

Supplement. The supplement related to this article is available online at: https://doi.org/10.5194/jm-38-231-2019-supplement.

Author contributions. AJ, AKMW, JS, MK, and MFGW collected the samples and processed the data. AJ, AKMW, JS, MK, and MFGW drafted the article and all authors critically revised it. The final version was approved by all authors.

Competing interests. The authors declare that they have no conflict of interest.

Acknowledgements. Amos Winter (University of Puerto Rico) and colleagues and boat crews at the Isla Magueyes Marine Laboratories (Puerto Rico) are gratefully acknowledged for the help offshore and providing lab facilities during the sampling campaign in 2012. We thank Fynn Wulf (GEOMAR) for stable isotope measurements on foraminiferal calcite and Hydroisotop $\mathrm{GmbH}$ for stable isotope analyses of the seawater samples. We acknowledge Sebastian Meier and Birgit Mohr (University of Kiel) for the help with scanning electron microscope photographs of our foraminifers and Birgit Lübben and Nele Vollmar (MARUM, Bremen) for their help with size and weight measurements. We gratefully thank Kirsty Edgar for handling the manuscript and two anonymous reviewers for their constructive comments which helped to improve our article.

Financial support. This research has been supported by the German Research Foundation DFG (grant SCHO605/8-1 and KU2259/19).

The article processing charges for this open-access publication were covered by a Research Centre of the Helmholtz Association.

Review statement. This paper was edited by Kirsty Edgar and reviewed by two anonymous referees.

\section{References}

Almogi-Labin, A.: Population dynamics of planktic Foraminifera and Pteropoda - Gulf of Aqaba, Red Sea, P. K. Akad. Wet.Amsterd., 87, 481-511, 1984. 
André, A., Weiner, A., Quillévéré, F., Aurahs, R., Morard, R., Douady, C. J., de Garidel-Throron, T., Escarguel, G., de Vargas, C., and Kučera, M.: The cryptic and the apparent reversed: Lack of genetic differentiation within the morphologically diverse plexus of the planktonic foraminifer Globigerinoides sacculifer, Paleobiology, 39, 21-39, 2013.

Aurahs, R., Treis, Y., Darling, K., and Kučera, M.: A revised taxonomic and phylogenetic concept for the planktonic foraminifer species Globigerinoides ruber based on molecular and morphometric evidence, Mar. Micropaleontol., 79, 1-14, 2011.

Babin, S., Carton, J., Dickey, T., and Wiggert, J.: Satellite evidence of hurricane - induced phytoplankton blooms in an oceanic desert, J. Geophys. Res.-Oceans, 109, 1-21, 2004.

Bé, A. W. H.: Families: Globigerinidae and Globorotaliida, Fiche no. 108, in: Fiches d'intification du zooplankton, edited by: Frasier, J. H., Conseil International pour l'Exploration de la Mer, Copenhagen, 1-9, 1967.

Bé, A. W. H.: An ecological zoogeographic and taxonomic review of recent planktonic foraminifera, in: Oceanic Micropaleontology, edited by: Ramsay A. T. S., Academic Press, London, 1977.

Bé, A. W. H.: Gametogenic calcification in a spinose planktonic foraminifer, Globigerinoides sacculifer (Brady), Mar. Micropaleontol., 5, 283-310, 1980.

Bé, A. W. H. and Tolderlund, D.: Distribution and ecology of living planktonic foraminifera in surface waters of the Atlantic and Indian Oceans, in: The Micropalaeontology of Oceans, edited by: Funnel, B. and Riedel, W., Cambridge University Press, Cambridge, 105-149, 1971.

Bé, A. W. H., Vilks, G., and Lott, L.: Winter distribution of planktonic foraminifera between the Grand Banks and the Caribbean, Micropaleontology, 17, 31-42, 1971.

Bidigare, R. R., Ondrusek, M. E., and Brooks, J. M.: Influence of the Orinoco River outflow on distributions of algal pigments in the Caribbean Sea, J. Geophys. Res.-Oceans, 98, 2259-2269, 1993.

Bijma, J., Erez, J., and Hemleben, C.: Lunar and semi-lunar reproductive cycles in some spinose planktonic foraminifers, J. Foramin. Res., 20, 117-127, 1990.

Blake, E. S., Kimberlain, T. B., Berg, R. J., Cangialosi, J. P., and Beven, L.: Tropical cyclone report: Hurricane Sandy (AL182012), 22-29 October 2012, National Hurricane Center, $12,1-10,2013$.

Brooks, W. W.: Distribution of recent foraminifera from the southern coast of Puerto Rico, Micropaleontology, 19, 385-416, 1973.

Byrne, D., Suarez, G., and McCann, W.: Muertos Trough subduction - Microplate tectonics in the northern Caribbean?, Nature, 317, 420-421, 1985.

Chérubin, L. and Richardson, P. L.: Caribbean current variability and the influence of the Amazon and Orinoco freshwater plumes, Deep-Sea Res. Pt. I, 54, 1451-1473, 2007.

Corredor, J. E. and Morell, J. M.: Seasonal variation of physical and biogeochemical features in eastern Caribbean surface water, J. Geophys. Res.-Oceans, 106, 4517-4525, 2001.

Cushman, J. A.: Shallow-water foraminifera of the Tortugas region, Carnegie Inst., Washington, 1922.

Darling, K. F., Thomas, E., Kasemann, S. A., Seears, H. A., Smart, C. W., and Wade, C. M.: Surviving mass extinction by bridging the benthic/planktic divide, P. Natl. Acad. Sci. USA, 106, 1262912633, 2009.
Ellis, B. F. and Messina, A. R.: Catalogue of foraminifera, Micropaleontology Press, New York, 1940.

Erez, J. and Honjo, S.: Comparison of isotopic composition of planktonic foraminifera in plankton tows, sediment traps and sediments, Palaeogeogr. Palaeocl., 33, 129-156, 1981.

Erez, J., Almogi-Labin, A., and Avraham, S.: On the life history of planktonic foraminifera: Lunar reproduction cycle in Globigerinoides sacculifer (Brady), Paleoceanography, 6, 295-306, 1991.

Farmer, E. C., Kaplan, A., deMenocal, P. B., and Lynch-Stieglitz, J.: Corroborating ecological depth preferences of planktonic foraminifera in the tropical Atlantic with the stable oxygen isotope ratios of core top specimens, Paleoceanography, 22, PA3205, https://doi.org/10.1029/2006PA001361, 2007.

Fischer, G. and Wefer, G.: Use of Proxies in Paleoceanography: Examples from the South Atlantic, Springer, Berlin, Heidelberg, 1999.

Fornshell, J. A.: Planktonic protozoan populations of five West Indian reefs, Atoll Res. Bull., 553, 93-102, 2005.

Froelich, P. N., Atwood, D. K., and Giese, G. S.: Influence of Amazon River discharge on surface salinity and dissolved silicate concentration in the Caribbean Sea, Deep-Sea Res., 25, 735-744, 1978.

Gallegos, A.: Descriptive physical oceanography of the Caribbean Sea, in: Small Islands: Marine science and sustainable development coastal and estuarine studies, edited by: Maul, G., American Geophysical Union, Washington DC, 36-55, 1996.

Gilbes, F., Armstrong, R. A., Webb, R. M., and Müller-Krager, F. E.: SeaWiFS helps assess hurricane impact on phytoplankton in Caribbean Sea, EOS T. Am. Geophys. Un., 82, 529-533, 2001.

Glover, L.: Geology of the Coamo area, Puerto Rico, and its relation to the volcanic arc-trench association, US Govt. Print. Off., Washington DC, 1971.

Gordon, A. L.: Circulation of the Caribbean Sea, J. Geophys. Res., 72, 6207-6223, 1967.

Hammer, Ø., Harper, D., and Ryan, P.: PAST: Palaeontological statistics software package for education and data analysis, Palaeontol. Electron., 4, 1-9, 2001.

Harbers, A. T. E.: Habitats and chemical characteristics of modern planktonic foraminifera in the Atlantic Ocean, $\mathrm{PhD}$ thesis, University Kiel, Germany, 76 pp., 2011.

Hemleben, C., Spindler, M., and Anderson, O.: Modern Planktonic Foraminifera, Springer, New York, 1989.

Hut, G.: Stable isotope reference samples for geochemical and hydrological investigations, in: Consultants Group meeting, 1618 September 1985, Vienna, Austria, International Atomic Energy Agency (I.A.E.A.), 1987.

IBM Corporation: IBM ${ }^{\circledR}$ SPSS ${ }^{\circledR}$ Statistics, Armonk, 1989-2011.

Jacob, S. D., Shay, L. K., Mariano, A. J., and Black, P. G.: The 3D oceanic mixed layer response to Hurricane Gilbert, J. Phys. Oceanogr., 30, 1407-1429, 2000.

Jentzen, A., Nürnberg, D., Hathorne, E. C., and Schönfeld, $\mathrm{J} .: \mathrm{Mg} / \mathrm{Ca}$ and $\delta^{18} \mathrm{O}$ in living planktic foraminifers from the Caribbean, Gulf of Mexico and Florida Straits, Biogeosciences, 15, 7077-7095, https://doi.org/10.5194/bg-15-70772018, 2018a.

Jentzen, A., Schönfeld, J., and Schiebel, R.: Assessment of the effect of increasing temperature on the ecology and assemblage structure of modern planktic foraminifers in the Caribbean and surrounding seas, J. Foramin. Res., 48, 251-272, 2018b. 
Jones, J. I.: The relationship of planktonic foraminiferal populations to water masses in the western Caribbean and lower Gulf of Mexico, B. Mar. Sci., 18, 946-982, 1968.

Jones, J. I.: The ecology and distribution of living planktonic foraminifera in the Straits of Florida, in: Symposium of Recent South Florida foraminifera, edited by: Bock, W., Lynts, G., Smith, S., Wright, R., Hay, W., and Jones, J., Miami Geological Society, Maimi, 245 pp., 1971.

Jonkers, L., Reynolds, C. E., Richey, J., and Hall, I. R.: Lunar periodicity in the shell flux of planktonic foraminifera in the Gulf of Mexico, Biogeosciences, 12, 3061-3070, https://doi.org/10.5194/bg-12-3061-2015, 2015.

Kahn, M. I.: Non-equilibrium oxygen and carbon isotopic fractionation in tests of living planktonic foraminifera, Oceanol. Acta, 2, 195-208, 1979.

Kim, S.-T. and O'Neil, J. R.: Equilibrium and nonequilibrium oxygen isotope effects in synthetic carbonates, Geochim. Cosmochim. Ac., 61, 3461-3475, 1997.

Kruskal, J. B.: Nonmetric multidimensional scaling: a numerical method, Psychometrika, 29, 115-129, 1964.

Kučera, M.: Planktonic foraminifera as tracers of past oceanic environments, in: Proxies in Late Cenozoic Paleoceanography, edited by: Hillaire-Marcel, C. and de Vernal A., Elsevier, Amsterdam, 213-262, 2007.

Kučera, M., Silye, L., Weiner, A. K., Darling, K., Lübben, B., Holzmann, M., Pawlowski, J., Schönfeld, J., and Morard, R.: Caught in the act: anatomy of an ongoing benthic-planktonic transition in a marine protist, J. Plankton Res., 39, 436-449, 2017.

Lin, H.-L., Wang, W.-C., and Hung, G.-W.: Seasonal variation of planktonic foraminiferal isotopic composition from sediment traps in the South China Sea, Mar. Micropaleontol., 53, 447-460, 2004.

Lin, H.-L., Sheu, D. D.-D., Yang, Y., Chou, W.-C., and Hung, G.W.: Stable isotopes in modern planktonic foraminifera: Sediment trap and plankton tow results from the South China Sea, Mar. Micropaleontol., 79, 15-23, 2011.

Lončarić, N., Brummer, G.-J. A., and Kroon, D.: Lunar cycles and seasonal variations in deposition fluxes of planktic foraminiferal shell carbonate to the deep South Atlantic (central Walvis Ridge), Deep-Sea Res. Pt. I, 52, 1178-1188, 2005.

Loose, T.: Turbulent transport of benthonic foraminifera, Contr. Cushman Found. Foram. Res., 21, 164-166, 1970.

Masson, D. and Scanlon, K. M.: The neotectonic setting of Puerto Rico, Geol. Soc. Am. Bull., 103, 144-154, 1991.

Meilland, J., Siccha, M., Weinkauf, M. F. G., Jonkers, L., Morard, R., Baranowski, U., Baumeister, A., Bertlich, J., Brummer, G.-J., Debray, P., Fritz-Endres, T., Groeneveld, J., Magerl, L., Munz, P., Rillo, M. C., Schmidt, C., Takagi, H., Theara, G., and Kučera, M.: Highly replicated sampling reveals no diurnal vertical migration but stable species-specific vertical habitats in planktonic foraminifera, J. Plankton Res., 41, 127-141, 2019.

Morrison, J. M. and Nowlin, W. D.: General distribution of water masses within the eastern Caribbean Sea during the winter of 1972 and fall of 1973, J. Geophys. Res.-Oceans, 87, 4207-4229, 1982.

Murray, J.: Biogenic indicators of suspended sediment transport in marginal marine environments: quantitative examples from SW Britain, J. Geol. Soc., 144, 127-133, 1987.
Nelder, J. A. and Wedderburn, R. W.: Generalized linear models, J. R. Stat. Soc. A-G., 135, 370-384, 1972.

NHC: National Hurricane Center and Central Pacific Hurricane Center, available at: https://www.nhc.noaa.gov (last access: 17 June 2019), 2014.

Poore, R. Z., Tedesco, K. A., and Spear, J. W.: Seasonal flux and assemblage composition of planktic foraminifers from a sedimenttrap study in the Northern Gulf of Mexico, J. Coastal Res., 63, 6-19, 2013.

Ravelo, A. C. and Hillaire-Marcel, C.: The use of oxygen and carbon isotopes of foraminifera in paleoceanography, in: Proxies in Late Cenozoic Paleoceanography, edited by: Hillaire-Marcel, C. and de Vernal, A., Elsevier, Amsterdam, 213-262, 2007.

R Core Team: R: A Language and Environment for Statistical Computing, available at: https://www.R-project.org/, last access: 16 April 2014.

Rebotim, A., Voelker, A. H. L., Jonkers, L., Waniek, J. J., Meggers, H., Schiebel, R., Fraile, I., Schulz, M., and Kucera, M.: Factors controlling the depth habitat of planktonic foraminifera in the subtropical eastern North Atlantic, Biogeosciences, 14, 827-859, https://doi.org/10.5194/bg-14-827-2017, 2017.

Retailleau, S., Howa, H., Schiebel, R., Lombard, F., Eynaud, F., Schmidt, S., Jorissen, F., and Labeyrie, L.: Planktic foraminiferal production along an offshore-onshore transect in the southeastern Bay of Biscay, Cont. Shelf Res., 29, 1123-1135, 2009.

Retailleau, S., Schiebel, R., and Howa, H.: Population dynamics of living planktic foraminifers in the hemipelagic southeastern Bay of Biscay, Mar. Micropaleontol., 80, 89-100, 2011.

Retailleau, S., Eynaud, F., Mary, Y., Abdallah, V., Schiebel, R., and Howa, H.: Canyon heads and river plumes: How might they influence neritic planktonic Foraminifera communities in the SE Bay of Biscay?, J. Foramin. Res., 42, 257-269, 2012.

Richey, J. N., Thirumalai, K., Khider, D., Reynolds, C. E., Partin, J. W., and Quinn, T. M.: Considerations for Globigerinoides ruber (white and pink) paleoceanography: Comprehensive insights from a long-running sediment trap, Paleoceanogr. Paleocl., 34, 353-373, https://doi.org/10.1029/2018PA003417, 2019.

Rückert-Hilbig, A.: Megalospheric gamonts of Rosalina globularis d'Orbigny 1826, Cymbaloporetta bulloides (d'Orbigny 1839) and Cymbaloporetta milletti (Heron-Allen and Earland 1915) (Foraminifera) with differently constructed swimming apparatus, Tübinger Mirkopaläontol. Mitteilungen, 1, 1-69, 1983.

Schiebel, R. and Hemleben, C.: Planktic foraminifers in the modern ocean, Springer, Berlin, Heidelberg, 2017.

Schiebel, R., Hiller, B., and Hemleben, C.: Impacts of storms on Recent planktic foraminiferal test production and $\mathrm{CaCO}_{3}$ flux in the North Atlantic at $47^{\circ} \mathrm{N}, 20^{\circ} \mathrm{W}$ (JGOFS), Mar. Micropaleontol., 26, 115-129, 1995.

Schiebel, R., Bijma, J., and Hemleben, C.: Population dynamics of the planktic foraminifer Globigerina bulloides from the eastern North Atlantic, Deep-Sea Res. Pt. I, 44, 1701-1713, 1997.

Schiebel, R., Waniek, J., Bork, M., and Hemleben, C.: Planktic foraminiferal production stimulated by chlorophyll redistribution and entrainment of nutrients, Deep-Sea Res. Pt. I, 48, 721-740, 2001.

Schiebel, R., Smart, S. M., Jentzen, A., Jonkers, L., Morard, R., Meilland, J., Michel, E., Coxall, H. K., Hull, P. M., GaridelThoron, T., Aze, T., Quillévéré, F., Ren, H., Sigman, D. M., Vonhof, H. B., Martinez-Garcia, A., Kučera, M., Bijma, J., Spero, 
H. J., and Haug, G. H.: Advances in planktonic foraminifer research: New perspectives for paleoceanography, Revue de Micropaléontologie, 61, 113-138, 2018.

Schindelin, J., Arganda-Carreras, I., Frise, E., Kayning, V., Longair, M., Pietzsch, T., Preibisch, S., Rueden, C., Saalfeld, S., Schmid, B., Tinevez, J.-Y., White, D. J., Hartenstein, V., Eliceiri, K., Tomancak, P., and Cardona, A.: Fiji: An open-source platform for biological-image analysis, Nat. Methods, 9, 676-682, 2012.

Schmuker, B.: The influence of shelf vicinity on the distribution of planktic foraminifera south of Puerto Rico, Mar. Geol., 166, 125-143, 2000a.

Schmuker, B.: Recent planktic foraminifera in the Caribbean Sea: Distribution, ecology and taphonomy, PhD thesis, ETH Zürich, Switzerland, 165 pp., 2000 b.

Schmuker, B. and Schiebel, R.: Planktic foraminifers and hydrography of the eastern and northern Caribbean Sea, Mar. Micropaleontol. 46, 387-403, 2002.

Seiglie, G.: Foraminifers of Guyanilla Bay and their use as environmental indicators, Rev. Esp. Micropaleontol., 7, 453-487, 1975.

Siccha, M., Schiebel, R., Schmidt, S., and Howa, H.: Short-term and small-scale variability in planktic foraminifera test flux in the Bay of Biscay, Deep-Sea Res. Pt. I, 64, 146-156, 2012.

Sliter, W. V.: Laboratory experiments on the life cycle and ecologic controls of Rosalina globularis d'Orbigny, J. Protozool., 12, 210-215, 1965.

Spear, J. W., Reynolds, C. E., and Poore, R. Z.: Seasonal flux and assemblage composition of planktic foraminifera from the northern Gulf of Mexico, 2008-2010, US Geological Survey, OpenFile Rep. 2011-1215, 16 pp., 2011.

Spearman, C.: The proof and measurement of association between two things, Am. J. Psychol., 15, 72-101, 1904.

Spero, H. and DeNiro, M.: The influence of symbiont photosynthesis on the $\delta^{18} \mathrm{O}$ and $\delta^{13} \mathrm{C}$ values of planktonic foraminiferal shell calcite, Symbiosis, 4, 213-228, 1987.

Spero, H. J. and Lea, D. W.: Intraspecific stable isotope variability in the planktic foraminifera Globigerinoides sacculifer: Results from laboratory experiments, Mar. Micropaleontol., 22, 221234, 1993

Spero, H. J. and Williams, D. F.: Extracting environmental information from planktonic foraminiferal $\delta^{13} \mathrm{C}$ data, Nature, 335, 717$719,1988$.
Spezzaferri, S., Kučera, M., Pearson, P. N., Wade, B. S., Rappo, S., Poole, C. R., Morard, R., and Stalder, C.: Fossil and genetic evidence for the polyphyletic nature of the planktonic foraminifera "Globigerinoides", and description of the new genus Trilobatus, PLoS One, 10, e0128108, https://doi.org/10.1371/journal.pone.0128108, 2015.

Spindler, M., Hemleben, C., Bayer, U., Bé, A., and Anderson, O.: Lunar periodicity of reproduction in the planktonic foraminifer Hastigerina pelagica, Mar. Ecol.-Prog. Ser., 1, 61-64, 1979.

Steph, S., Regenberg, M., Tiedemann, R., Mulitza, S., and Nürnberg, D.: Stable isotopes of planktonic foraminifera from tropical Atlantic/Caribbean core-tops: Implications for reconstructing uppper ocean stratification, Mar. Micropaleontol., 71, 1-19, 2009.

Tedesco, K. A. and Thunell, R. C.: Seasonal and interannual variations in planktonic foraminiferal flux and assemblage composition in the Cariaco Basin, Venezuela, J. Foramin. Res., 33, 192 210, 2003.

Tedesco, K., Thunell, R., Astor, Y., and Muller-Karger, F.: The oxygen isotope composition of planktonic foraminifera from the Cariaco Basin, Venezuela: Seasonal and interannual variations, Mar. Micropaleontol., 62, 180-193, 2007.

Tedesco, K. A., Spear, J. W., Tappa, E., and Poore, R. Z.: Seasonal flux and assemblage composition of planktic foraminifera from the northern Gulf of Mexico, U.S. Geological Survey Open, Virginia, File Report 2009-1293, 19 pp., 2009.

Weiner, A. K. M., Weinkauf, M. F. G., Kurasawa, A., Darling, K. F., and Kučera, M.: Genetic and morphometric evidence for parallel evolution of the Globigerinella calida morphotype, Mar. Micropaleontol., 114, 19-35, 2015.

Weinkauf, M. F. G., Bonitz, F. G. W., Martini, R., and Kučera, M.: Extinctions in marine plankton preceded by stabilizing selection, bioRxiv, 531947, https://doi.org/10.1101/531947, 2019.

Zhao, M., Liu, Z., Li, H.-C., Zeng, C., Yang, R., Chen, B., and Yan, $\mathrm{H}$.: Response of dissolved inorganic carbon (DIC) and $\delta^{13} \mathrm{C}_{\text {DIC }}$ to changes in climate and land cover in SW China karst catchments, Geochim. Cosmochim. Ac., 165, 123-136, 2015. 